\title{
Three new genera and seven new species of trypanorhynch cestodes (family Eutetrarhynchidae) from manta rays, Mobula spp. (Mobulidae) from the Gulf of California, Mexico
}

\author{
Ronald A. Campbell ${ }^{1,2}$ and Ian Beveridge ${ }^{3}$ \\ ${ }^{1}$ Department of Biology, University of Massachusetts-Dartmouth, N. Dartmouth, Massachusetts, USA; \\ ${ }^{2}$ Current address: 415 Highfield Road, Salem, Virginia 24153, USA; \\ ${ }^{3}$ Department of Veterinary Science, University of Melbourne, Veterinary Clinical Centre, Werribee, Victoria 3030, Australia
}
Key words: Cestoda, Trypanorhyncha, Eutetrarhynchidae, Fellicocestus, Mobulocestus, Hemionchos, taxonomy, new genera, Mobulidae

\begin{abstract}
Three new genera of eutetrarhynchid trypanorhynch cestodes are described from Mobula spp. (Mobulidae) from the Gulf of California, Mexico. Fellicocestus mobulae gen. et sp. n. from the gall bladder of Mobula japonica (Müller et Henle) is distinguished by elongate bothria, a pars bothrialis equal in length to the pars vaginalis, masses of gland cells in the pars vaginalis and an heteromorphous armature in which hook rows arise from a central file of hooks on the bothrial surface of the tentacle and terminate in a central file on the antibothrial surface. Species of Mobulocestus gen. n. occur in the nephridial system and cloaca of rays and are characterized by two bothria, an heteroacanthous armature with hook rows beginning on the bothrial surface and terminating on the antibothrial surface, and by hooks at the beginnings of rows with an apical cavity. M. nephritidis sp. n. and M. lepidoscolex sp. n., both from the nephridial system of Mobula thurstoni (Lloyd) are differentiated by testis number and by the presence of scale-like microtriches on the tegument of the scolex of M. lepidoscolex. M. mollis sp. n., from the cloaca of Mobula thurstoni is distinguished by testis number (97-111 in M. lepidoscolex, 20-22 in M. nephriticus and 48-70 in M. mollis). Hemionchos gen. n. from the spiral valve of Mobula spp. has two bothria, an heteroacanthous armature, hook rows arising on the bothrial surface and terminating on the antibothrial surface and hooks at the beginning of rows with an apical cavity. It differs from Mobulocestus in having a distinctive basal armature and both hook files 1 and 1' on the bothrial surface, but has an additional, small, satellite hook adjacent to each hook 1'. H. striatus $\mathrm{sp}$. n. from the spiral valve of Mobula thurstoni and M. japonica is differentiated by having a basal armature of closely packed arrays of small, uncinate hooks. H. mobulae sp. n. from the spiral valve of Mobula japonica and M. munkiana Notarbartolo di Sciari, differs in testis number and in having large, flattened hooks in the basal armature. H. maior sp. n., from the spiral valve of $M$. japonica, is larger, differing in both the number of testes and in the basal armature.
\end{abstract}

The elasmobranch family Mobulidae Rafinesque, 1810 contains the manta or devil rays, of which there are ten currently recognized species (Last and Stevens 1994). In spite of their wide-spread occurrence in oceans of the world, no species of the cestode order Trypanorhyncha Diesing, 1863 have previously been reported from them (Palm 2004).

In this paper, we report three new genera from mobulids collected in the Gulf of California, Mexico, including species inhabiting the gall bladder, the cloaca and the nephridial system, localisations previously unreported for adult trypanorhynch cestodes, as well as in the more usual site of the spiral valve.

\section{MATERIALS AND METHODS}

Specimens of Mobula spp. were collected in the Gulf of California, Mexico (local name Baja California) (also known as the Sea of Cortez) by local fisherman. Cestodes collected by J.N. Caira were fixed in $10 \%$ formalin in situ or were removed from the hosts and relaxed in water or water containing $5 \%$ lidocaine and were then fixed in AFA (Pritchard and Kruse 1982).
Whole mounts were prepared by staining in Harris' haematoxylin, Mayer's paracarmine or celestine blue, dehydrated in a graded ethanol series, cleared in methyl salicylate and mounted in Canada balsam.

Tentacles of some species were dissected free from the scolex and mounted individually in balsam. In these cases, it was not possible to determine the orientation of the tentacle.

Morphological terminology for trypanorhynch cestodes follows Campbell and Beveridge (1994) except that the attachment organs are referred to as bothria following Jones et al. (2004).

Dollfus (1942) distinguished hooks numbered on the bothrial surface of the tentacle from those on the antibothrial surface by adding a prime to the former group. Beveridge et al. (2004) dealing with hook rows which ran from the antibothrial to the bothrial surface distinguished the hooks of the external surface with a prime. In the following descriptions, hook rows run from the bothrial to the antibothrial surface and a prime is used to distinguish hooks on the external surface.

Drawings were made with the aid of a drawing tube attached to an Olympus BH microscope. Measurements were made with an ocular micrometer. All measurements are presented in micrometres, unless otherwise stated, as the range

Address for correspondence: I. Beveridge, University of Melbourne, Veterinary Clinical Centre, Werribee 3030, Victoria, Australia. Phone: ++61 397312 285; Fax:++61 397312 263; E-mail: ibeve@unimelb.edu.au 
followed, in parentheses, by the mean and the number of specimens measured (n). Specimens have been deposited in the Instituto de Biología, Universidad Nacional Autónoma de México, Mexico City, Mexico (IBUNAM), the Unites States National Parasite Collection, Beltsville, Maryland, USA (USNPC) and the Lawrence R. Penner Parasitology Collection, University of Connecticut, Storrs, Connecticut, USA (LRP).

Host nomenclature follows Eschmeyer (1998) except that the family name Mobulidae is used for the hosts following Last and Stevens (1994).

\section{RESULTS}

\section{Fellicocestus gen. n.}

Diagnosis. Large cestodes with numerous segments. Scolex acraspedote; two elongate bothria; pars bothrialis and pars vaginalis subequal. Metabasal armature heteroacanthous; hooks heteromorphous, solid; single, central file of hooks on bothrial surface of tentacle; hook rows ascend from central file, terminating on antibothrial surface as a single file. Basal swelling present; distinctive armature absent. Tentacle sheaths sinuous; bulb elongate; prebulbar organ present; retractor muscle originates at base of bulb. Segments craspedote, elongate. Genital pores marginal, alternate irregularly. Internal seminal vesicle present, external seminal vesicle absent; testes in two lateral groups, preovarian. Ovary at posterior extremity of segment; vitelline follicles circum-medullary. Uterus simple, median, saccate in gravid segments; uterine pore absent. Adults in elasmobranchs.

Type species: Fellicocestus mobulae sp. n.

$\mathrm{E}$ t y $\mathrm{m}$ o $\mathrm{log}$ y: The generic name is derived from fel, fellis, Latin for gall.

Differential diagnosis: Paired bothria and the possession of a typical heteroacanthous armature indicate that the species belongs to the family Eutetrarhynchidae Guiart, 1927. The genus differs in the possession of a central file of distinctive hooks in the centre of the internal surface of the tentacle. The hooks of this file are distinctive morphologically in having a bifid and laterally divergent hook guard, giving the hook a cruciform appearance when viewed apically.

\section{Fellicocestus mobulae sp. n.}

Figs. 1-12

Description. Long slender cestodes, 195-312 (235, $\mathrm{n}=5$ ) $\mathrm{mm}$ long, maximum width $3.8 \mathrm{~mm}$, with numerous segments. Scolex acraspedote 800-1,260 (1,010, n $=5$ ) long, maximum width in region of pars bulbosa 270-320 (280, $\mathrm{n}=5)$. Two elongate bothria; pars bothrialis 380-550 (460, $\mathrm{n}=5)$ long, 210-320 (270, $\mathrm{n}=$ 2) wide. Pars vaginalis shorter than or equal to pars bothrialis, $340-500(400, \mathrm{n}=5)$ long; sheaths relatively straight anteriorly, slightly sinuous posteriorly; pars vaginalis with numerous sub-globular glandular structures between sheaths immediately anterior to bulbs.
Bulbs 310-450 (400, $\mathrm{n}=5)$ long, 50-70 (60, $\mathrm{n}=5)$ wide; retractor muscle originates at base of bulb; gland cells absent within bulb; prebulbar organ present; pars post bulbosa highly variable, $50-350(150, \mathrm{n}=5)$ long.

Fully everted tentacle 300-350 long, 20-23 (22, n = 4 ) in diameter in metabasal region; with prominent basal swelling 25-30 $(27, \mathrm{n}=4)$ in diameter. Armature heteroacanthous, heteromorphous; hooks solid. Hook rows begin on bothrial surface, terminate on antibothrial surface. Basal armature almost homeomorphous with decrease in hook size along rows. Metabasal armature with single file of enlarged hooks on bothrial surface. Hooks of file 1 uncinate with very broad handle and cruciform hook guard (seen from above), total length 13, base length 10. Hook rows opposite, ascend from central file of enlarged hooks; hooks 2(2') erect, uncinate, 11 long, with short base, 7 long; hooks 3(3') to $5\left(5^{\prime}\right)$ erect uncinate, similar in size, 10 long, base 4-5; hooks $6\left(6^{\prime}\right)$ to 10 uncinate, total length $7-8$, base $4-5$ long, gradually diminishing in size. Hooks 10 form central file on antibothrial surface of tentacle. Rows terminate as inverted V-s on antibothrial surface.

Mature segments craspedote, 1,500-1,930 $(1,720, \mathrm{n}=$ 5) long, $1,430-1,600(1,500, \mathrm{n}=5)$ wide; velum $50-100$ $(80, \mathrm{n}=5)$ long; genital pore alternating irregularly, in posterior half of segment margin, 580-850 $(720, \mathrm{n}=5)$ or $38-49(42, n=5) \%$ of segment length from posterior end. Cirrus sac slender, elongate, extending to midline of segment, 450-630 (490, $\mathrm{n}=5)$ long, 50-140 (90, $\mathrm{n}=$ 5) wide; cirrus unarmed, up to 900 long when everted; distal cirrus straight, more proximal region sinuous, leading to internal seminal vesicle $150-250(180, \mathrm{n}=5)$ by $40-110(80, n=5)$; pars prostatica of vas deferens adjacent to internal seminal vesicle; vas deferens enters cirrus sac, coils anteriorly with single coil extending anterior to cirrus sac, then greatly coiled, descends posteriorly towards ovarian isthmus. Testes distributed in two multi-layered bands on either side of medulla; bands about two testes wide; testes 130-190 (160, n = $10)$ by $50-90(64, \mathrm{n}=10)$; total number of testes 140 $157(148, \mathrm{n}=5)$ with $17-30(21, \mathrm{n}=5)$ post-vaginal, $45-55(49, \mathrm{n}=5)$ pre-vaginal and $74-81(77, \mathrm{n}=5)$ anti-poral. Vagina tubiform, enters genital atrium posterior to cirrus sac; proximal vagina sinuous, expanded to form seminal receptacle in gravid segments. Ovary fourlobed, lobes 260-330 (300, $\mathrm{n}=5)$ by $70-120(100, \mathrm{n}=$ $5)$; Mehlis' gland posterior to ovarian isthmus, laterally elongated, maximum diameter $150(150, \mathrm{n}=5)$. Uterus tubiform, extends from Mehlis' gland almost to anterior extremity of segment; developing uteri with 20-25 short lateral diverticula; diverticula enlarge in early gravid segments; fully developed uterus saccate, filling segment. Vitelline follicles circum-medullary, greater concentration of follicles in lateral quarters of segment; follicles $35-60(46, \mathrm{n}=10)$ by $12-25(19, \mathrm{n}=10)$. Osmoregulatory canals paired; ventral canal sinuous, 40 $60(53, \mathrm{n}=5)$ in diameter, joined at posterior extremity of each segment by single transverse canal 13 

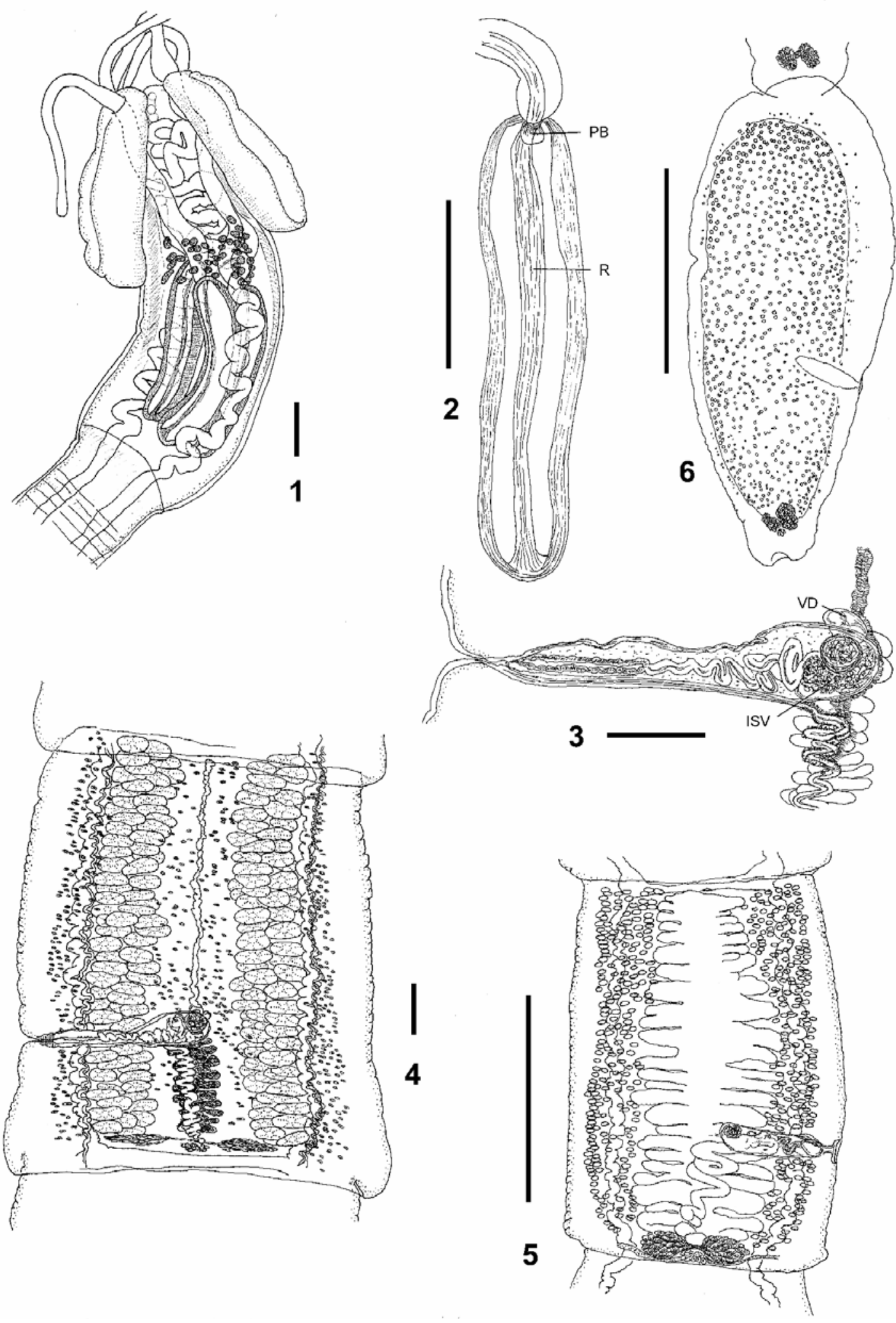

Figs. 1-6. Fellicocestus mobulae gen. et sp. n. from the gall bladder of Mobula japonica. Fig. 1. Scolex. Fig. 2. Tentacular bulb. Fig. 3. Cirrus sac and vagina. Fig. 4. Mature segment. Fig. 5. Post-mature segment with developing uterus. Fig. 6. Gravid segment. Abbreviations: ISV - internal seminal vesicle; PB - prebulbar organ; R - retractor muscle; VD - vas deferens. Scale bars: Figs. $1-4=0.1 \mathrm{~mm}$; Figs. 5, $6=1.0 \mathrm{~mm}$. 

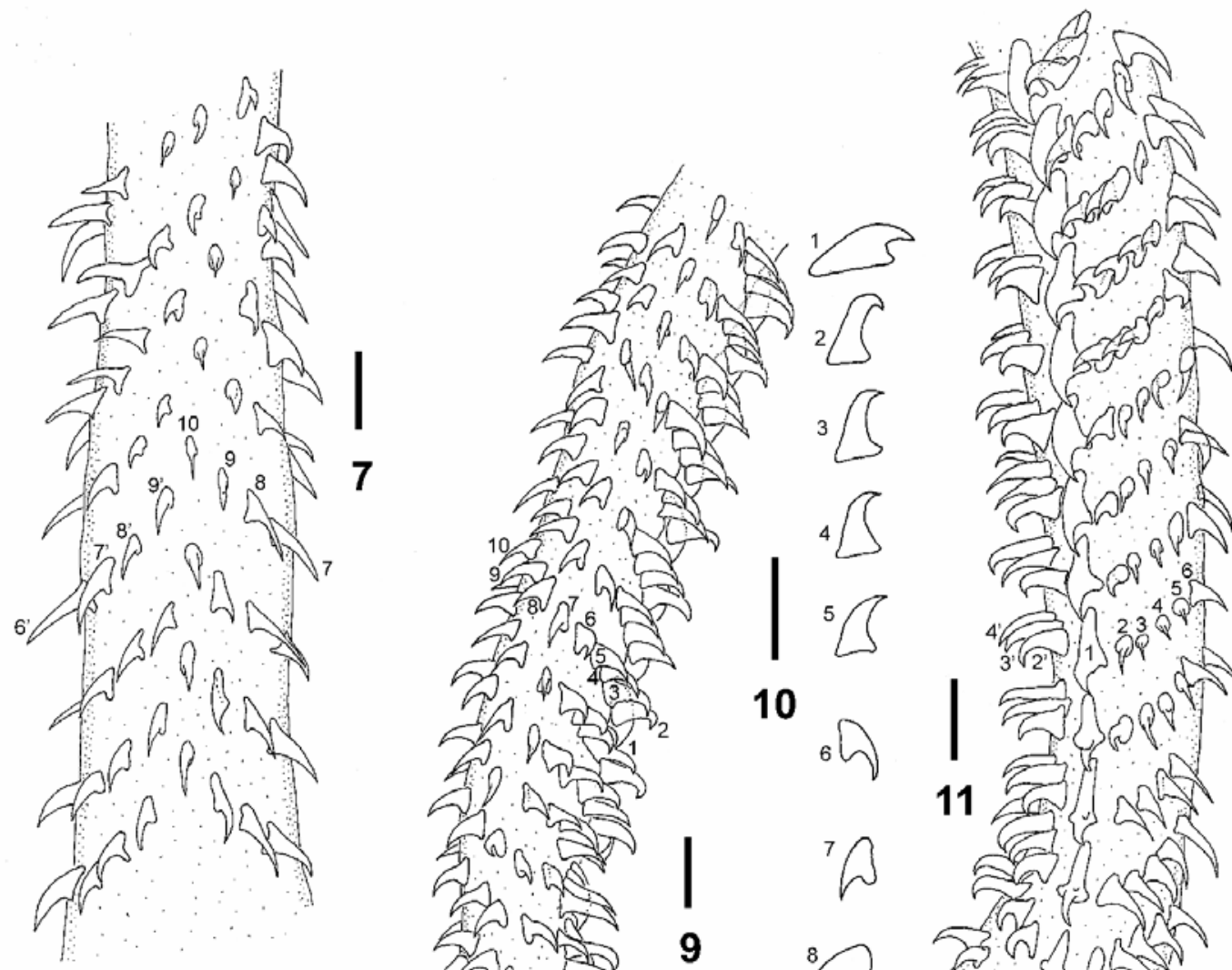

11
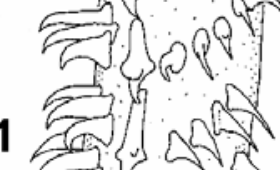

$n$

9
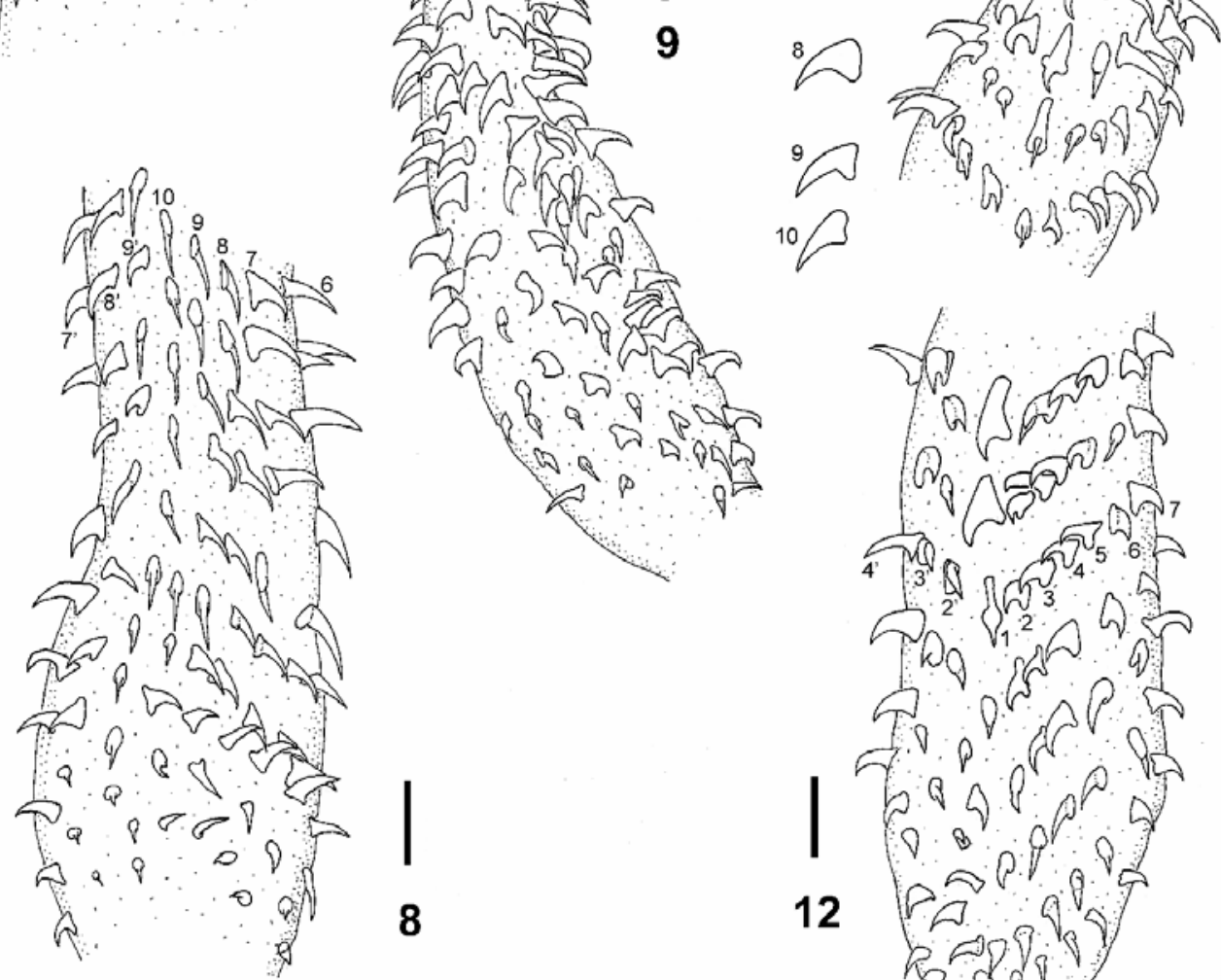

8

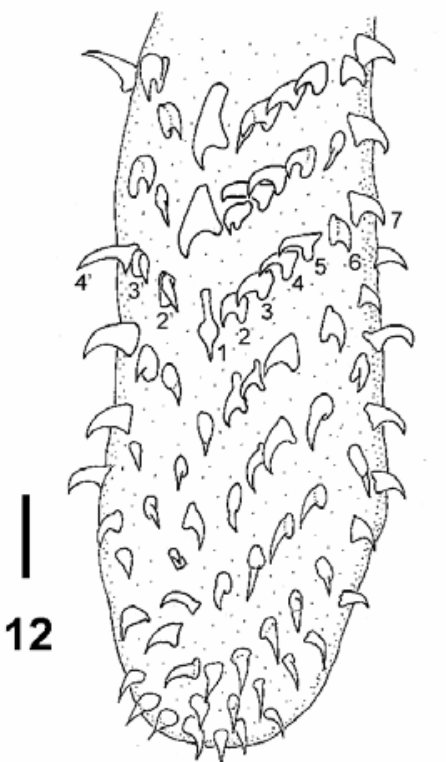

Figs. 7-12. Fellicocestus mobulae gen. et sp. n. from the gall bladder of Mobula japonica. Tentacular armature. Fig. 7. Antibothrial surface, metabasal region, external surface on left-hand side. Fig. 8. Antibothrial surface, basal region, external surface on left-hand side. Fig. 9. Internal surface, basal and metabasal region, bothrial surface on right-hand side. Fig. 10. Profiles of hooks 1-10 of principal rows. Fig. 11. Bothrial surface, basal and metabasal region, external surface on left-hand side. Fig. 12. Bothrial surface, basal region, external surface on left-hand side. Scale bars $=0.01 \mathrm{~mm}$. 
in diameter; dorsal canal narrow sinuous, 7-10 $(9, \mathrm{n}=$ $5)$ in diameter; genital ducts pass ventral to canals. Gravid segments 2,100-3,800 $(2,910, \mathrm{n}=5)$ long by $1,050-1,670(1,310, \mathrm{n}=5)$ wide; genital pore to posterior end $650-1,550(1,120, \mathrm{n}=5)$ or $31-41(38, \mathrm{n}=5) \%$ from posterior end.

$\mathrm{M}$ a t e r i a 1 e x a m i n e d: Holotype from gall bladder of Mobula japonica (Müller et Henle, 1841), Punta Arena, Gulf of California, Mexico $\left(23^{\circ} 35^{\prime} \mathrm{N}, 109^{\circ} 26^{\prime} \mathrm{W}\right)$, 25.vi.1996 (IBUNAM 5452); 12 paratypes, same data (IBUNAM 5453, USNPC 97899); from Mobula sp., 12 specimens, La Paz, Gulf of California, Mexico, 8.ix.1993 (USNPC 97900).

E t y m o log y: The species name is derived from the genitive case of the host name, Mobula.

\section{Remarks}

This unusual cestode is the first adult trypanorhynch reported from the gall bladder of an elasmobranch host. In addition to its localisation, it also exhibits a number of unusual morphological features. The paired bothria and the possession of a typical heteroacanthous armature indicate that the species belongs to the family Eutetrarhynchidae Guiart, 1927. The species differs however in the possession of a central file of distinctive hooks in the centre of the bothrial surface of the tentacle. The hooks of this file are quite distinctive morphologically in having a bifid and laterally divergent hook guard, giving the hook a cruciform appearance when viewed apically (Fig. 11). No known eutetrarhynchid genus has a distinctive file of hooks in the midline of the bothrial surface of the tentacle as well as in the reflection plane on the antibothrial surface of the tentacle (Campbell et Beveridge 1994). On each side of the bothrial central file, ascending rows of hooks run to the antibothrial surface of the tentacle, where hooks number 10 form a central file on the antibothrial surface of the tentacle (Fig. 7).

The pars bothrialis in this species is as long as the pars vaginalis and relatively short bulbs, characters which differentiate it from most eutetrarhynchid genera except for Mecistobothrium Heinz et Dailey, 1974. Fellicocestus possesses a prebulbar organ, in common with all eutetrarhynchid genera, but lacks gland cells within the bulb attached to the retractor muscle.

The unusual arrangement of the tentacular armature beginning with a single central file of hooks is sufficient to warrant the erection of a new genus for which the name Fellicocestus is proposed to indicate the unusual localisation of the species in the gall bladder of its host.

\section{Mobulocestus gen. n.}

Diagnosis. Small cestodes with few segments. Scolex acraspedote; two bothria; pars bothrialis shorter than pars vaginalis. Metabasal armature heteroacanthous. Hooks heteromorphous, solid, with apical cavity; single, central file of hooks on bothrial surface of tentacle; hook rows ascend from central file, terminating on antibothrial surface in reflection plane of bothrial surface. Basal swelling and distinctive armature absent. Tentacle sheaths sinuous; bulbs elongate; prebulbar organ present; retractor muscle originates at base of bulb. Segments craspedote or acraspedote, elongate. Genital pores marginal, alternate irregularly. Internal seminal vesicle present, external seminal vesicle present or absent; testes in two lateral groups, preovarian. Ovary at posterior extremity of segment; vitelline follicles circum-medullary. Uterus simple, median, saccate in gravid segments; uterine pore absent. Adults in elasmobranchs.

Type species: Mobulocestus nephritidis sp. n.

E t y m o l o g y: The new generic name is based on the host genus, Mobula.

Differential diagnosis: Hook rows begin on the bothrial surface of the tentacle and terminating on the antibothrial surface and a single file of hooks in the midline of both the bothrial and antibothrial surfaces of the tentacle as in Fellicocestus, but hooks possess a cavity near their tip.

\section{Remarks}

The new genus resembles Fellicocestus in possessing two bothria, an heteroacanthous armature with hook rows beginning on the bothrial surface of the tentacle and terminating on the antibothrial surface and a single file of hooks in the midline of both the bothrial and antibothrial surfaces of the tentacle. The new genus differs in having the pars bothrialis much shorter than the pars vaginalis, compared with being of equal length in Fellicocestus, and in lacking masses of gland cells in the region of the pars vaginalis. In Fellicocestus, the hooks are simple solid hooks, while in the new genus the initial hooks of the principal rows have a prominent cavity at their apex, a form of hook never previously reported in trypanorhynch cestodes.

The new genus is also unique in being parasitic in the urinary system of its elasmobranch hosts.

\section{Mobulocestus nephritidis sp. $\mathrm{n}$.}

Figs. 13-20

Description. Slender cestodes, mature and gravid specimens $7.5-17.5(9.7, \mathrm{n}=5) \mathrm{mm}$ long, maximum width 220-330 (290, $\mathrm{n}=5)$, strobila with 45-97 $(67, \mathrm{n}$ $=5)$ segments. Scolex acraspedote 820-1,100 (960, $\mathrm{n}=$ 5) long, maximum width in region of pars vaginalis 170-250 $(210, \mathrm{n}=5)$. Tegument of scolex covered with numerous, fine, transverse annulations from level of bothria and continuing posteriorly over segments. Two oval bothria; margin of bothria entire; pars bothrialis 210-290 (250, $\mathrm{n}=5)$. Pars vaginalis longer than pars bothrialis, 350-620 (480, $\mathrm{n}=5)$ long; sheaths often straight initially then very slightly sinuous; pars vaginalis with numerous, sub-globular glandular structures between sheaths and tegument, beginning slightly posterior to pars bothrialis, terminating in anterior region of pars bulbosa. Bulbs 390-450 (430, n = 5) long, $50-70(61, \mathrm{n}=5)$ wide; retractor originates at base of bulb; gland cells absent within bulb; prebulbar organ present; pars post bulbosa either absent or short, 15-40 long. 

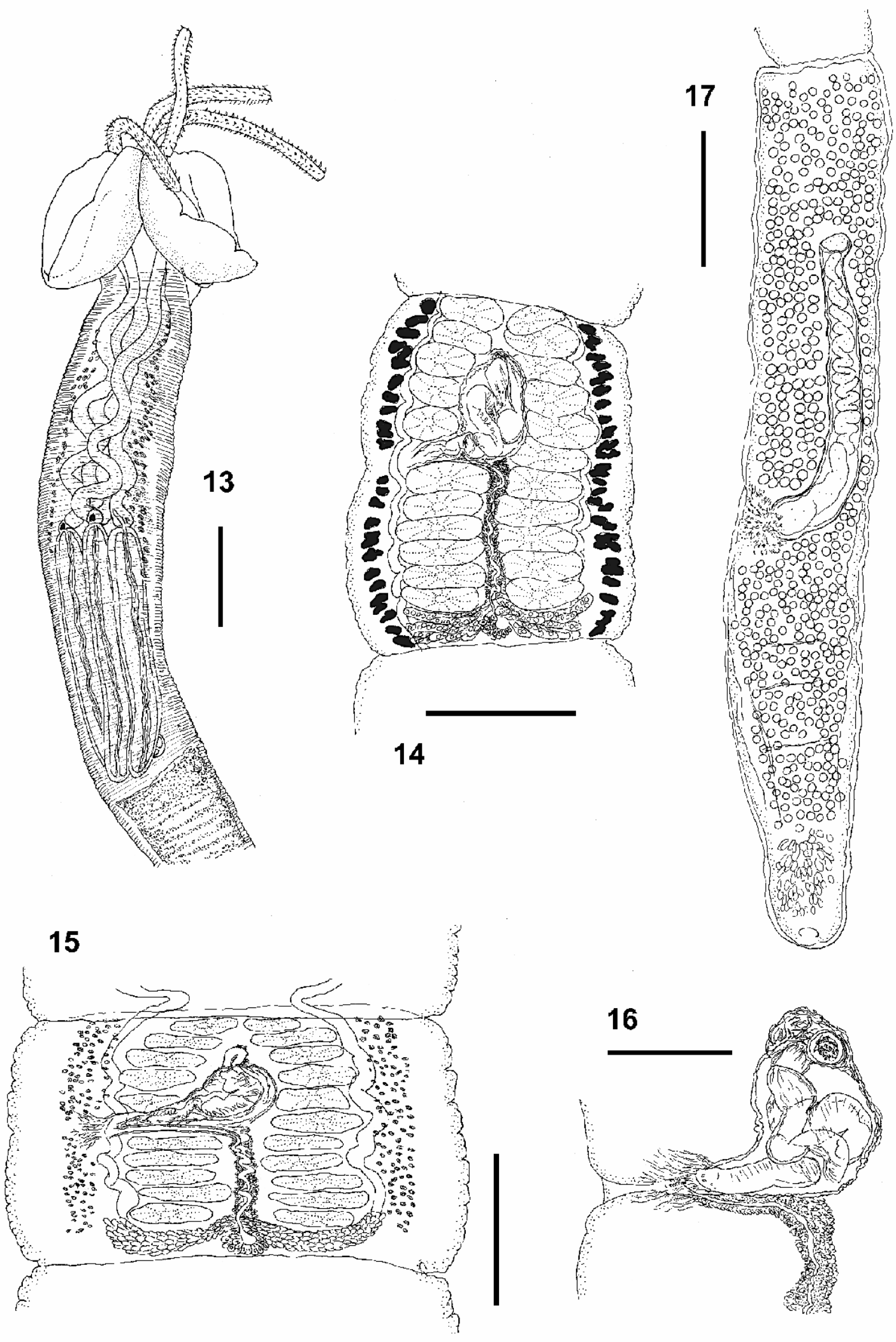

16

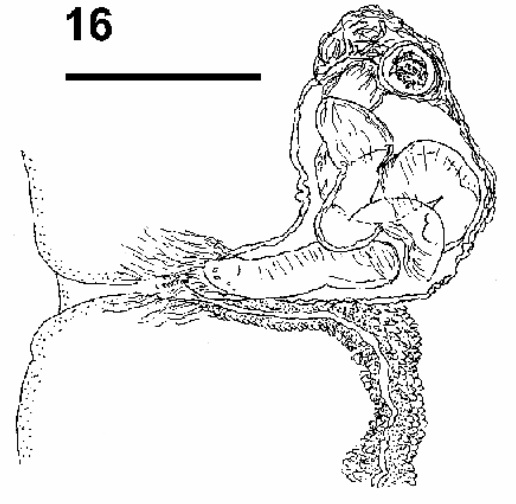

Figs. 13-17. Mobulocestus nephritidis sp. n. from the nephridial system of Mobula thurstoni. Fig. 13. Scolex. Fig. 14. Mature segment. Fig. 15. Pre-mature segment. Fig. 16. Cirrus sac and vagina. Fig. 17. Gravid segment. Scale bars: Figs. $13,14,17=0.1$ mm; Figs. 15, $16=0.05 \mathrm{~mm}$. 


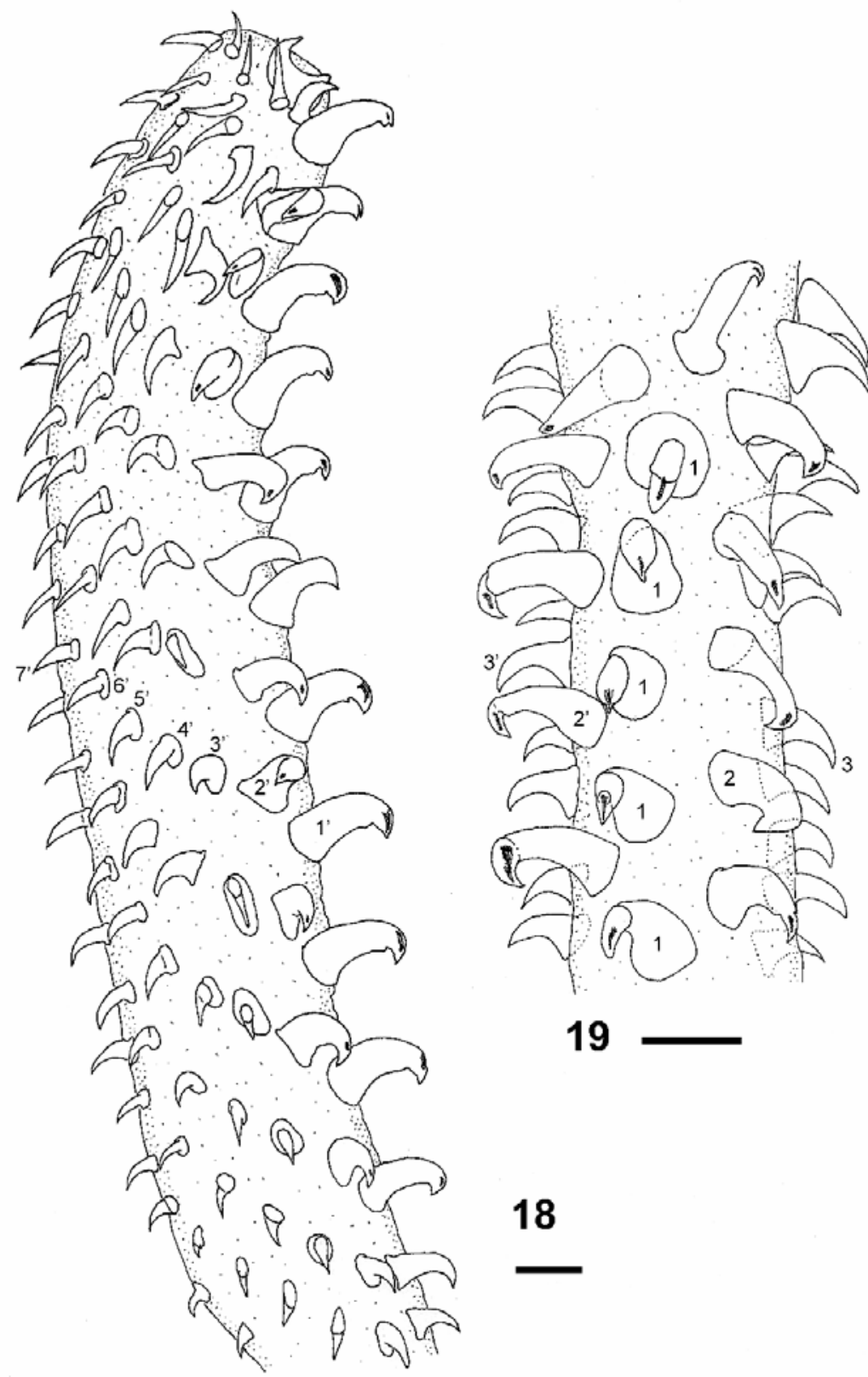

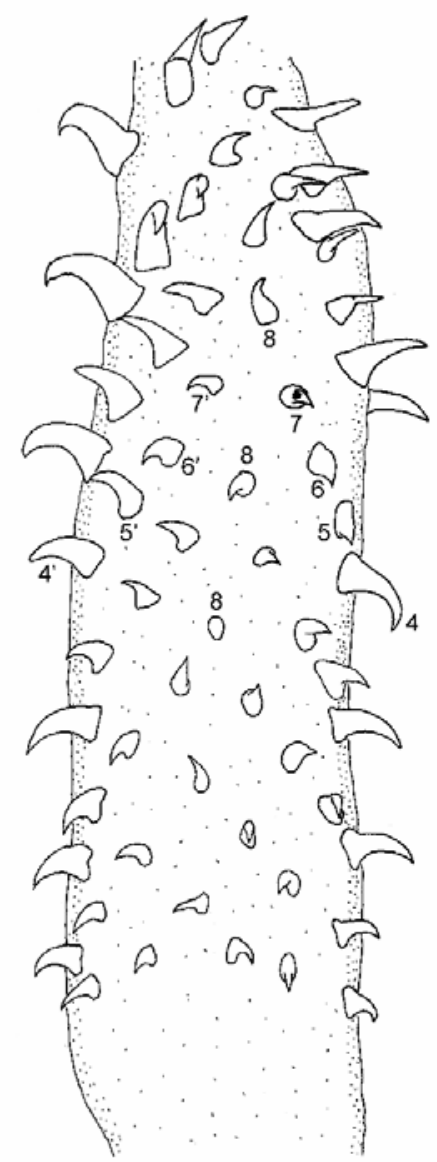

20

Figs. 18-20. Mobulocestus nephritidis sp. n. from the nephridial system of Mobula thurstoni. Tentacular armature. Fig. 18. External surface, basal and metabasal regions, bothrial surface on right-hand side. Fig. 19. Bothrial surface, metabasal region, external surface on left-hand side. Fig. 20. Antibothrial surface, basal region, external surface on left-hand side. Scale bars $=0.01$ $\mathrm{mm}$.

Everted tentacle up to 300 long, 23-25 (24, $\mathrm{n}=5)$ wide in metabasal region; without prominent basal swelling, 28-38 (32, $\mathrm{n}=5)$ in diameter at base. Armature heteroacanthous, heteromorphous; hooks solid. Hook rows begin on bothrial surface, terminate on antibothrial surface. Distinctive basal armature absent. Metabasal armature with single file of enlarged hooks on bothrial surface. Principal rows symmetrical, opposite, beginning at file 1; rows consist of 8 hooks; opposing rows meet on opposite surface to form inverted Vshaped formations. Hooks of file 1 erect, uncinate, 16$17(17, n=5)$ long, base 7-8 $(8, n=5)$; lower aspect of recurved part of hook tip with distinct, abrupt kink; upper margin of recurved part of hook with refractile cavity, giving hook a rostrate appearance. Hook rows ascend from central file of enlarged hooks; hooks 2(2') similar in shape to hooks 1 , with cavity in hook near tip, length $13-16(14, n=5)$, base $6-8(7, n=5)$; remaining 
hooks (3-5) uncinate with elongate base but without cavity near tip; hooks 3(3') 8-13 $(10, \mathrm{n}=5)$ long, base 5-8 (7, n = 5); hooks 4(4') 9-13 $(11, \mathrm{n}=5)$ long, base 4-6 (5, n = 5); hooks 5(5') 8-10 (9, $\mathrm{n}=5)$ long, base 4$5(5, \mathrm{n}=5)$; hooks $6\left(6^{\prime}\right)-8\left(8^{\prime}\right)$ becoming falciform; hooks 6(6') 7-10 $(9, \mathrm{n}=5)$ long, base $3-5(4, \mathrm{n}=5)$; hooks 7(7') 7-10 $(8, \mathrm{n}=5)$ long, base $3-4(4, \mathrm{n}=5)$; hooks 8 form central file on antibothrial surface of tentacle, 7-8 (8, n = 5) long, base 3-4 (4, n=5). Rows of hooks terminate as inverted $\mathrm{V}$-shaped formations on antibothrial surface of tentacle.

Mature segments very slightly craspedote, surface covered with regular, fine annulations, 190-410 (300, n $=5)$ long, 230-330 $(280, \mathrm{n}=5)$ wide; genital pore most commonly unilateral with occasional segments exhibiting alternate orientation, in middle of segment margin, 110-190 $(150, \mathrm{n}=5)$ or $46-58(52, \mathrm{n}=5) \%$ from posterior end. Cirrus sac slender, elongate, extending to midline of segment, distal extremity curved abruptly anteriorly and extending along midline of segment, 100-200 $(146, \mathrm{n}=5)$ long, 26-90 $(50, \mathrm{n}=5)$ wide; cirrus unarmed; distal cirrus straight, more proximal region sinuous, leading to internal seminal vesicle 15-60 (30, n = 5 ) in diameter; vas deferens enters cirrus sac on dorsal or ventral side, coils anteriorly with single coil extending anterior to cirrus sac; descends towards ovarian isthmus, greatly coiled. Testes between longitudinal osmoregulatory canals, distributed in two columns on either side of medulla; testes $50-80(63, \mathrm{n}=10)$ by 15 $30(22, \mathrm{n}=10)$; total number of testes $20-22(21, \mathrm{n}=5)$ distributed as 5-6 $(5, \mathrm{n}=5)$ post-vaginal, 5-6 $(5, \mathrm{n}=5)$ pre-vaginal and $10-11(10, \mathrm{n}=5)$ anti-poral. Vagina tubiform, enters genital atrium posterior to cirrus sac; proximal vagina sinuous; seminal receptacle not observed. Ovary posterior, four-lobed, lobes 65-100 (83, n $=5)$ by $45-70(60, n=5)$; Mehlis' gland posterior to ovarian isthmus, maximum diameter $40-50(47, \mathrm{n}=5)$. Uterus tubiform, extends from Mehlis' gland almost to anterior extremity of segment; fully developed uterus saccate, filling segment anterior to ovary. Vitelline follicles circum-medullary; follicles $10-38(24, \mathrm{n}=10)$ in diameter. Osmoregulatory canals paired, sinuous; ventral canal 10 in diameter; dorsal canal narrow, 5 in diameter; genital ducts pass ventral to canals. Gravid segments $430-840(590, \mathrm{n}=5)$ by $180-320(240, \mathrm{n}=$ $5)$; genital pore to posterior end $210-550(300, n=5)$ or $26-65(45, \mathrm{n}=5) \%$ from posterior end.

M a t e r i a 1 ex a m in e d: Holotype from nephridial system of Mobula thurstoni (Lloyd, 1908), La Paz, Gulf of California, Mexico $\left(24^{\circ} 10^{\prime} \mathrm{N}, 110^{\circ} 17^{\prime} \mathrm{W}\right), \quad 10 . i x .1993$ (IBUNAM 5454); 11 paratypes, same data (IBUNAM 5455, USNPC 97901).

E t y $\mathrm{m}$ o $10 \mathrm{~g} \mathrm{y}$ : The species name, nephritidis, is derived from the Greek, nephros, for kidney, alluding to the localisation of the cestode in the nephridial system of the host.

\section{Remarks}

Mobulocestus nephritidis is one of three new species of trypanorhynch cestodes reported here from the nephridial system and cloaca of mobulid rays. It resembles Mobulocestus lepidoscolex sp. $\mathrm{n}$. in having prominent transverse striations on the scolex, this character serving to distinguish both species from Mobulocestus mollis $\mathrm{sp} . \mathrm{n}$. The three species are readily distinguishable on the basis of testis number (97-111 in M. lepidoscolex, 20-22 in M. nephritidis and 48-70 in M. mollis).

\section{Mobulocestus lepidoscolex sp. n.}

Figs. 21-26

Description. Slender cestodes, holotype (mature) $24.5 \mathrm{~mm}$ long, maximum width 260 . Scolex acraspedote $1,060-1,210(1,150, \mathrm{n}=3)$ long, maximum width in region of pars bulbosa 240-280 $(260, \mathrm{n}=3)$. Tegument of scolex and strobila covered with numerous, fine, scale-like microtriches. Two oval bothria, margin entire, but with pair of prominent ridges diverging from midpoint of posterior margin of bothrium, extending nearly to tentacular orifice; pars bothrialis 330-350 (343, n = 3) long, width 290. Pars vaginalis longer than pars bothrialis, 430-690 (570, $\mathrm{n}=3$ ) long; sheaths straight or slightly sinuous; pars vaginalis with numerous subglobular glandular structures between sheaths and tegument. Bulbs 500-540 (520, n = 3) long, 50-54 (52, $\mathrm{n}=3$ ) wide; retractor muscle originates at base of bulb, with prominent enlargement in anterior bulb region; gland cells absent within bulb; prebulbar organ present; pars post bulbosa $20-40(30, n=3)$ long.

Tentacle only partly everted, up to 250 long, 30-32 $(31, \mathrm{n}=3)$ in diameter in metabasal region; without prominent basal swelling, 32-35 $(34, \mathrm{n}=3)$ in diameter at base. Armature heteroacanthous, heteromorphous; hooks solid. Hook rows begin on bothrial surface, terminate on antibothrial surface. Distinctive basal armature absent. Metabasal armature with single file of enlarged rostrate hooks on bothrial surface. Hooks of file 1 erect, uncinate; lower aspect of recurved part of hook with distinct, abrupt kink; upper margin of recurved part of hook with refractile cavity, giving hook a mucronate or rostrate appearance. Hook rows ascend from central file of rostrate hooks; hooks 2(2') similar in shape to hooks 1 , smaller, rostrate, length 13-18 (16, $\mathrm{n}=5)$, base $8-9(8, \mathrm{n}=5)$; remaining hooks uncinate with elongate base but without cavity near tip; hooks 3(3') 8-14 (11, $\mathrm{n}=5)$ long, base 5-8 $(6, \mathrm{n}=5)$; hooks 4(4') 10-13 $(11, \mathrm{n}=5)$ long, base 4-5 $(5, \mathrm{n}=5)$; hooks 5(5') 7-10 (8, n = 5) long, base 3-5 (4, n = 5); hooks 6(6') 6-10 (8, n = 5) long, base 3-5 $(4, \mathrm{n}=5)$; hooks $7\left(7^{\prime}\right)$ 7-10 (8, n = 5) long, base 4-5 $(4, \mathrm{n}=5)$; hooks 8 form central file on antibothrial surface of tentacle, 8 $10(9, \mathrm{n}=5)$ long, base $3-4(3.5, \mathrm{n}=5)$. Rows of hooks terminate in inverted $\mathrm{V}$-shaped formations on antibothrial surface of tentacle. 

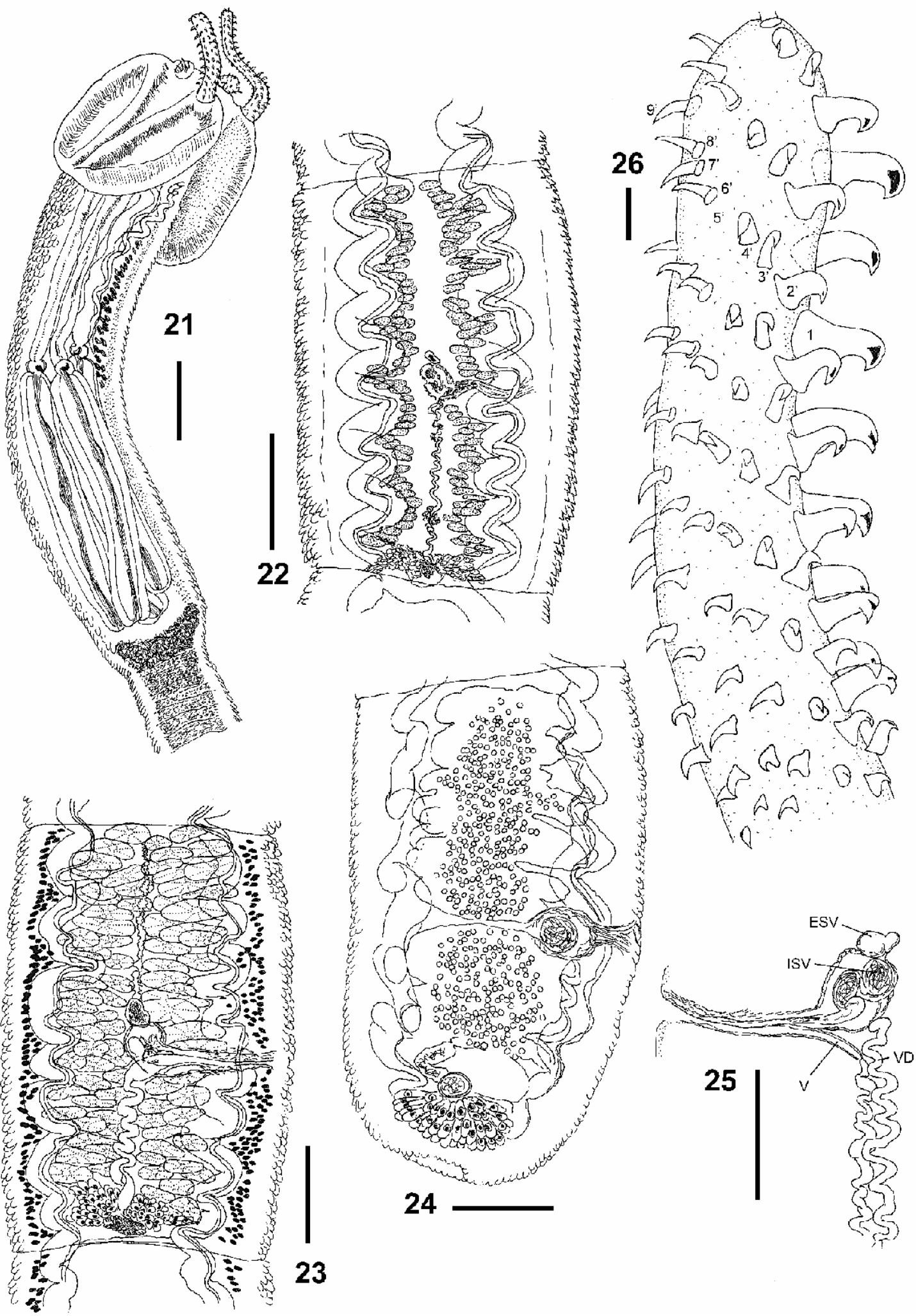

Figs. 21-26. Mobulocestus lepidoscolex sp. n. from the nephridial system of Mobula thurstoni. Fig. 21. Scolex. Fig. 22. Premature segment. Fig. 23. Mature segment. Fig. 24. Gravid segment. Fig. 25. Cirrus sac and vagina. Fig. 26. Tentacular armature, external surface, basal and metabasal region, bothrial surface on right-hand side. Abbreviations: ESV - external seminal vesicle; ISV - internal seminal vesicle; V - vagina; VD - vas deferens. Scale bars: Figs. $21-24=0.1 \mathrm{~mm}$; Fig. $25=0.05$ mm; Fig. $26=$ $0.01 \mathrm{~mm}$. 
Mature segments acraspedote, with scaliform surface, 400-820 (620, $\mathrm{n}=5)$ long, 410-500 (450, $\mathrm{n}=5)$ wide; genital pore alternating infrequently, near mid-point of segment margin, $190-380(300, \mathrm{n}=5)$ or $46-52(48, \mathrm{n}=$ $5) \%$ from posterior end. Cirrus sac slender, elongate, extending to midline of segment, distal extremity curved anteriorly, 180-230 $(210, \mathrm{n}=5)$ long, 45-100 $(70, \mathrm{n}=$ 5) wide; cirrus unarmed; distal cirrus straight, more proximal region sinuous, leading to internal seminal vesicle; external seminal vesicle on anterior aspect of proximal pole of cirrus sac; vas deferens coils anteriorly with single coil extending anterior to cirrus sac, descends towards ovarian isthmus, greatly coiled. Testes distributed in two bands on either side of medulla; bands $1-2$ testes wide; testes $45-80(60, \mathrm{n}=10)$ long by $15-35(22, \mathrm{n}=10)$ wide; total number of testes $97-111$ $(105, \mathrm{n}=5)$ distributed as $18-24(21, \mathrm{n}=5)$ postvaginal, 26-32 $(29, \mathrm{n}=5)$ pre-vaginal and 51-58 $(55, \mathrm{n}$ $=5$ ) anti-poral. Vagina tubiform, enters genital atrium posterior to cirrus sac; proximal vagina sinuous distended to form seminal receptacle in mature and gravid segments. Ovary four-lobed, lobes $110-160(130, \mathrm{n}=5)$ long by $85-110(97, \mathrm{n}=5)$ wide; lobules digitiform, arching posteriorly. Mehlis' gland posterior to ovarian isthmus, laterally elongated, maximum diameter 65-100 $(78, \mathrm{n}=5)$. Uterus tubiform, extends from Mehlis' gland almost to anterior extremity of segment; developing uteri with short lateral diverticula; fully developed uterus saccate, filling segment. Vitelline follicles circum-medullary, extending full length of segment, greater concentration of follicles in lateral quarters of segment; follicles $25-40(30, \mathrm{n}=10)$ in diameter. Osmoregulatory canals paired; ventral canal sinuous, 13$55(25, \mathrm{n}=5)$ in diameter; dorsal canal narrow sinuous, $5-8(6, \mathrm{n}=5)$ in diameter; genital ducts pass ventral to canals. Gravid segments $800-1,620(990, \mathrm{n}=5)$ by $300-450(370, \mathrm{n}=5)$; genital pore to posterior end 190 $750(460, n=5)$ or in posterior $24-57(44, n=5) \%$ of segment.

M a t e ri a 1 e x a m i n e d : Holotype from nephridial system of Mobula thurstoni (Lloyd, 1908), La Paz, Gulf of California, Mexico $\left(24^{\circ} 10^{\prime} \mathrm{N}, 110^{\circ} 17^{\prime} \mathrm{W}\right), \quad 10 . i x .1993$ (IBUNAM 5458); 5 paratypes, fragments, same data (IBUNAM 5459, USNPC 97902).

E t y m o lo g y: The specific name is derived from the Greek prefix lepido- meaning covered with scales and alluding to the scale-like microtriches covering the scolex.

\section{Remarks}

This species has the characteristic armature of the genus Mobulocestus, namely the central file of hooks on the bothrial surface of the tentacle and the first hooks of each row with an apical cavity. It is readily distinguished from congeners by the scale-like covering of both scolex and segments and the number of testes (97111 in M. lepidoscolex, 20-22 in M. nephriticus and 4870 in M. mollis).
Mobulocestus mollis sp. n.

Figs. 27-31

Description. Small cestodes, largest specimen (mature) $7.5 \mathrm{~mm}$ long, maximum width 260 , strobila with 48 craspedote segments. Scolex acraspedote $820-1,150$ $(980, \mathrm{n}=5)$ long, maximum width in region of pars vaginalis $200-250(230, \mathrm{n}=5)$. Tegument of scolex smooth. Two oval bothria; margin of bothria entire; pars bothrialis $290-370(340, \mathrm{n}=5)$. Pars vaginalis longer than pars bothrialis, 330-600 $(510, \mathrm{n}=5)$ long; sheaths straight or very slightly sinuous; numerous sub-globular glandular structures between sheaths and tegument, beginning in posterior part of pars vaginalis, terminating at end of pars bulbosa. Bulbs 320-500 (410, $\mathrm{n}=5)$ long, $50-70(58, \mathrm{n}=5)$ wide; retractor originates at base of bulb; gland cells absent within bulb; prebulbar organ present; pars post bulbosa absent.

Everted tentacle up to 400 long, 20-25 (24, n = 5) wide in metabasal region; without prominent basal swelling, 25-38 $(32, \mathrm{n}=5)$ in diameter at base. Armature heteroacanthous typical, heteromorphous; hooks solid. Hook rows begin on bothrial surface, terminate on antibothrial surface. Distinctive basal armature absent. Metabasal armature with single file of enlarged hooks on bothrial surface. Principal rows symmetrical, each row beginning at file $1 ; 10$ hooks per row; rows meet on opposite surface of tentacle forming inverted $\mathrm{V}$-shaped formations. Hooks of file 1 erect, uncinate, 13-14 (14, n $=5)$ long, base 8-9 $(9, n=5)$; lower aspect of recurved part of hook with distinct, abrupt kink; upper margin of tip hook with refractile cavity, giving hook a rostrate appearance. Hook rows ascend from central file of enlarged hooks; hooks 2(2') similar in shape to hooks 1 , with cavity in hook near tip, length $12-14(13, \mathrm{n}=5)$, base $5-7(6, \mathrm{n}=5)$; remaining hooks uncinate with elongate base but without cavity near tip; hooks 3(3') 7$8(7.5, \mathrm{n}=5)$ long, base 5-7 (6, $\mathrm{n}=5)$; hooks 4(4') 8$10(9, \mathrm{n}=5)$ long, base $6-8(7, \mathrm{n}=5)$; hooks $5\left(5^{\prime}\right) 9-10$ $(9, \mathrm{n}=5)$ long, base $6-7(6.5, \mathrm{n}=5)$; hooks $6\left(6^{\prime}\right) 7-8$ $(7.5, \mathrm{n}=5)$ long, base $4-5(4, \mathrm{n}=5)$; hooks 7(7') 7-8 $(6.5, \mathrm{n}=5)$ long, base 4-8 $(5, \mathrm{n}=5)$; hooks $8\left(8^{\prime}\right), 9\left(9^{\prime}\right)$ of similar shape, diminishing in size; hooks 10 form central file on antibothrial surface of tentacle, $4-5(5, \mathrm{n}$ =5) long, base 2-3 (3, $\mathrm{n}=5)$.

Mature segments very slightly craspedote, 250-450 (320, $\mathrm{n}=5)$ long, 170-260 (220, $\mathrm{n}=5)$ wide; genital pore alternating irregularly, in anterior half of segment margin, 64-68 $(66, \mathrm{n}=2) \%$ from posterior end. Cirrus sac slender, elongate, extending to midline of segment, distal extremity curved anteriorly, 135 long, 55 wide; cirrus unarmed; distal cirrus straight, more proximal region sinuous, leading to internal seminal vesicle 35 in diameter. Testes distributed in 4 columns, 2 on either side of medulla; testes $48-70(57, \mathrm{n}=10)$ long by $15-23$ $(10, \mathrm{n}=10)$ wide; total number of testes $24-36(30, \mathrm{n}=$ 5) with c. 3 post-vaginal, 4 pre-vaginal and 8 anti-poral in each layer. Vagina and seminal receptacle not seen. 

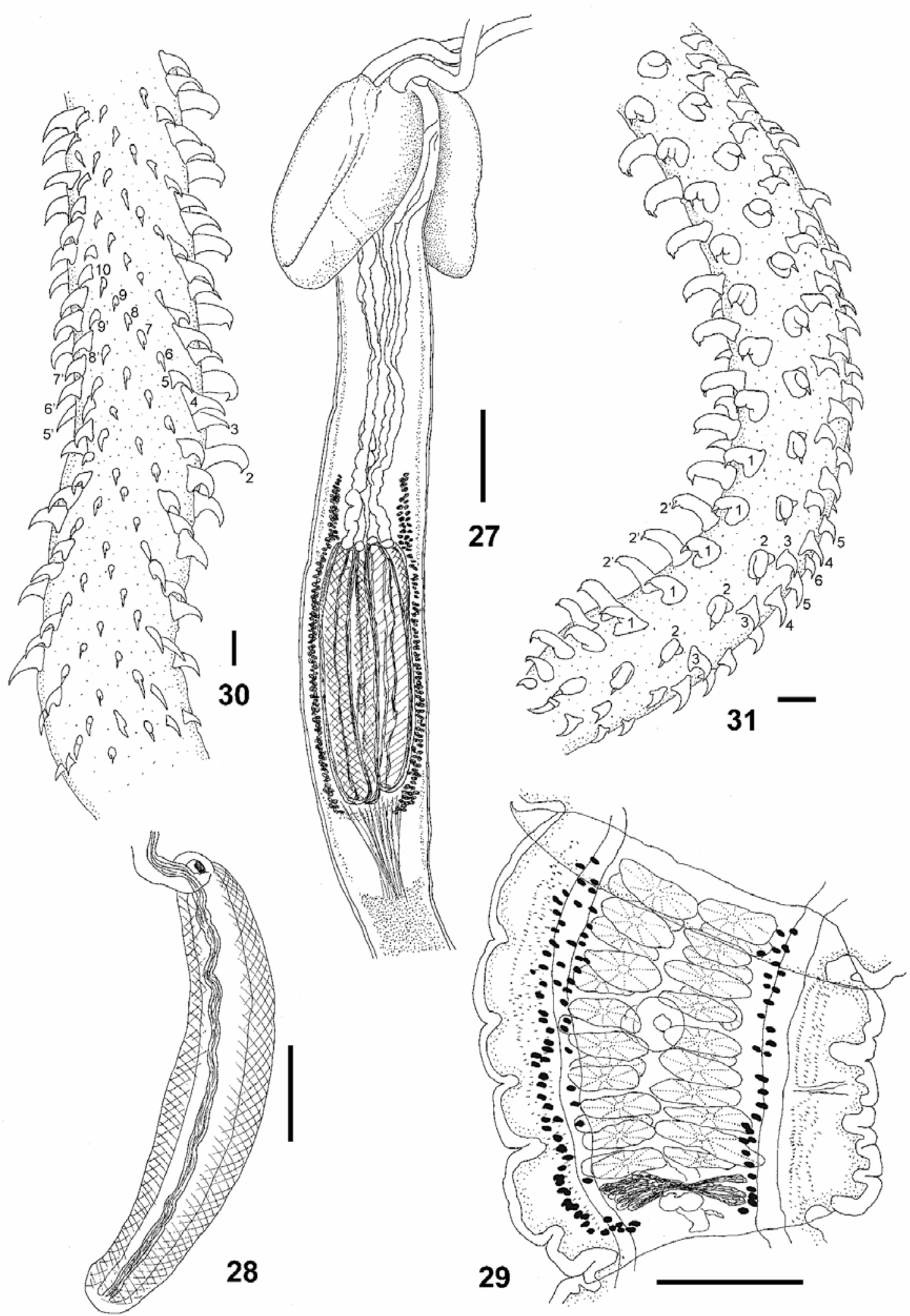

Figs. 27-31. Mobulocestus mollis sp. n. from the cloaca of Mobula thurstoni. Fig. 27. Scolex. Fig. 28. Tentacular bulb. Fig. 29. Mature segment. Fig. 30. Tentacular armature, antibothrial surface, basal and metabasal region, external surface on left-hand side. Fig. 31. Tentacular armature, bothrial surface, basal and metabasal region, external surface on right-hand side. Scale bars: Fig. $27=0.1 \mathrm{~mm}$; Figs. $28,29=0.05 \mathrm{~mm}$; Figs. 30, $31=0.01 \mathrm{~mm}$. 
Ovary four-lobed, lobes $48-68(55, \mathrm{n}=5)$ long by 28 $75(43, n=5)$ wide; Mehlis' gland posterior to ovarian isthmus, maximum diameter 35 . Uterus tubiform, extends from Mehlis' gland almost to anterior extremity of segment. Osmoregulatory canals paired; ventral canal sinuous, 5 in diameter; dorsal canal narrow sinuous, 3 in diameter; genital ducts pass ventral to canals. Gravid segments absent.

M a t e r i a 1 e x a m i n e d : Holotype from cloaca of Mobula thurstoni (Lloyd, 1908), La Paz, Gulf of California, Mexico $\left(24^{\circ} 10^{\prime} \mathrm{N}, 110^{\circ} 17^{\prime} \mathrm{W}\right), 10.1 x .1993$ (IBUNAM 5456); 8 paratypes, same data (IBUNAM 5457, USNPC 97903).

E t y m o log y: The specific name, mollis, Latin for smooth, alludes to the lack of scale-like microtriches on the scolex, a feature of the type species of the genus.

\section{Remarks}

Mobulocestus mollis is unusual as it occurs in the cloaca of its host. It is distinguished from M. lepidoscolex in having a smooth tegument and in having a smaller number of testes and the testes arranged in two completely overlapping layers.

\section{Hemionchos gen. n.}

Diagnosis. Small cestodes with few segments. Scolex acraspedote, with prominent transverse annulations; two bothria; pars bothrialis shorter than pars vaginalis. Armature heteroacanthous. Hooks heteromorphous, solid, with apical cavity; hooks 1, 1' separated on bothrial surface of tentacle; hook rows terminate on antibothrial surface; additional file of small hooks adjacent to hooks 1' on external surface. Basal swelling absent, distinctive armature present. Tentacle sheaths sinuous; bulbs elongate; prebulbar organ present; retractor muscle originates at base of bulb. Segments acraspedote, elongate. Genital pores marginal, alternate irregularly. Internal seminal vesicle present, external seminal vesicle absent; testes in two lateral groups, preovarian. Ovary at posterior extremity of segment; vitelline follicles circum-medullary. Uterus simple, median, saccate in gravid segments; uterine pore absent. Adults in elasmobranchs.

Type species: Hemionchos striatus sp. $\mathrm{n}$.

E t y m o lo g y: The generic name refers to the additional

tiny hooks adjacent to each hook 1', as they form a file of tiny hooks on one side only of the tentacle.

Differential diagnosis: Differentiated from other eutetrarhynchid genera except Mobulocestus in possessing hooks with a cavity at their tip. Distinguished from Mobulocestus in having a space between hook files 1 and 1' and in having a small accessory hook associated with each hook 1'.

\section{Remarks}

This new genus shares a number of characters with Fellicocestus and Mobulocestus, namely two bothria, an heteroacanthous armature and hook rows commencing on the bothrial surface and terminating on the antibothrial surface of the tentacle. The new genus differs however in two principal characters, the presence of a distinctive basal armature and the presence of paired hook files 1 and 1' on the bothrial surface of the tentacle. In Fellicocestus and Mobulocestus a single file of hooks 1 is present in the midline of the bothrial surface. In Hemionchos, adjacent to each hook 1' on the external surface of the tentacle, there is an additional tiny hook, herein indicated as a satellite hook (a) (Figs. 39, 48), which also distinguishes the genus. Hemionchos is similar to Mobulocestus in having the first hooks of the principal rows with a prominent cavity at the apex. All three species of the new genus described here have prominently annulated tegument on the scolex. This may also be a generic character, but the feature also occurs in M. nephriticus.

\section{Hemionchos striatus sp. n.}

Figs. $32-41$

Description. Small cestodes, mature specimens 1.73-2.70 (2.17, $\mathrm{n}=10) \mathrm{mm}$ long, maximum width 100-150 (120, $\mathrm{n}=10)$, with 4-7 $(5, \mathrm{n}=10)$ acraspedote segments. Scolex acraspedote 600-990 (800, $\mathrm{n}=10)$ long, maximum width in region of pars bulbosa 70-120 $(90, n=10)$. Tegument of scolex with regular, fine, transverse annulations. Two bothria, oval to subquadrate, slightly indented on posterior margin; internally two ridges extend from mid-line of posterior margin, diverge towards tentacle orifices; pars bothrialis 100-170 $(140, \mathrm{n}=10)$. Pars vaginalis longer than pars bothrialis, 370-570 (490, $\mathrm{n}=10)$ long; sheaths sinuous. Bulbs 210-380 (290, $\mathrm{n}=10)$ long, 25-40 (29, $\mathrm{n}=10)$ wide; retractor originates at base of bulb; gland cells absent within bulb; prebulbar organ present; pars post bulbosa absent.

Everted tentacle up to 200 long, 10-20 $(15, \mathrm{n}=10)$ wide in metabasal region; without prominent basal swelling, $13-25(20, \mathrm{n}=10)$ in diameter at base. Armature heteroacanthous typical, heteromorphous; hooks solid. Distinctive basal armature present, composed of band of small, uncinate hooks, 3-4 (3, n = 5) long, base $1-3(2, \mathrm{n}=5)$; c. 5 hook rows arranged in regular compact array, centre of band on internal surface closest to origin of tentacle from sheath; hook rows ascend distally around bothrial and antibothrial surfaces of tentacle so that on external surface band is distal to its origin on internal surface. Principal rows of metabasal armature begin distal to band of hooks. First 2-3 principal hook rows begin on internal surface, terminate on external surface; armature gradually rotates so that in more distal region of tentacle hook rows begin on bothrial surface, terminate on antibothrial surface. Principal rows alternate; 5 hooks per row; space present between hook files 1 and 1' on bothrial surface; additional small hook (alpha) adjacent to hooks 1 on external surface; hooks 4-6 (5, n = 5) long, base 3-4 (3, n = 5). Hooks $1\left(1^{\prime}\right)$ erect, uncinate, $12-14(13, \mathrm{n}=5)$ long, base $7-10$ 

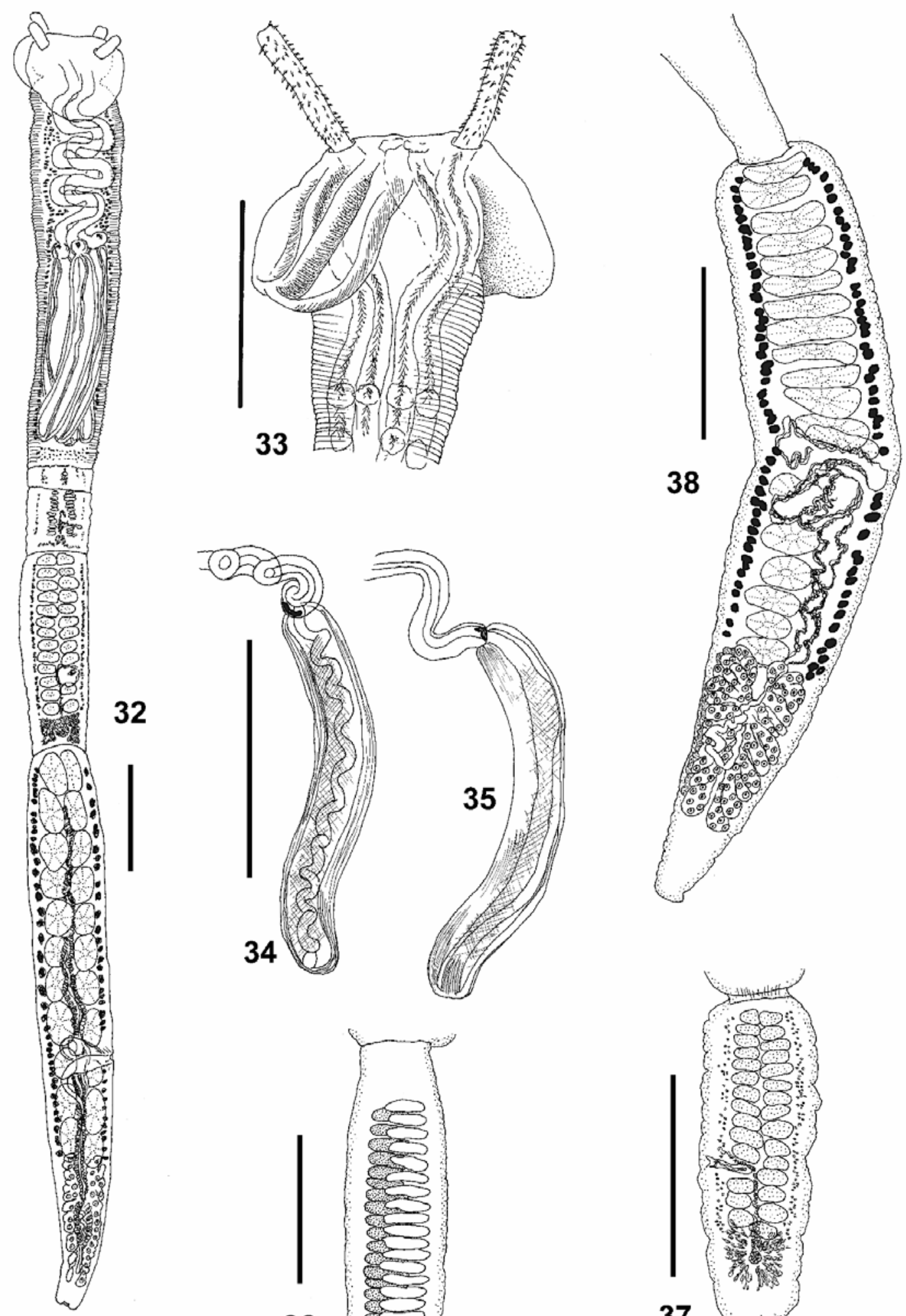

34
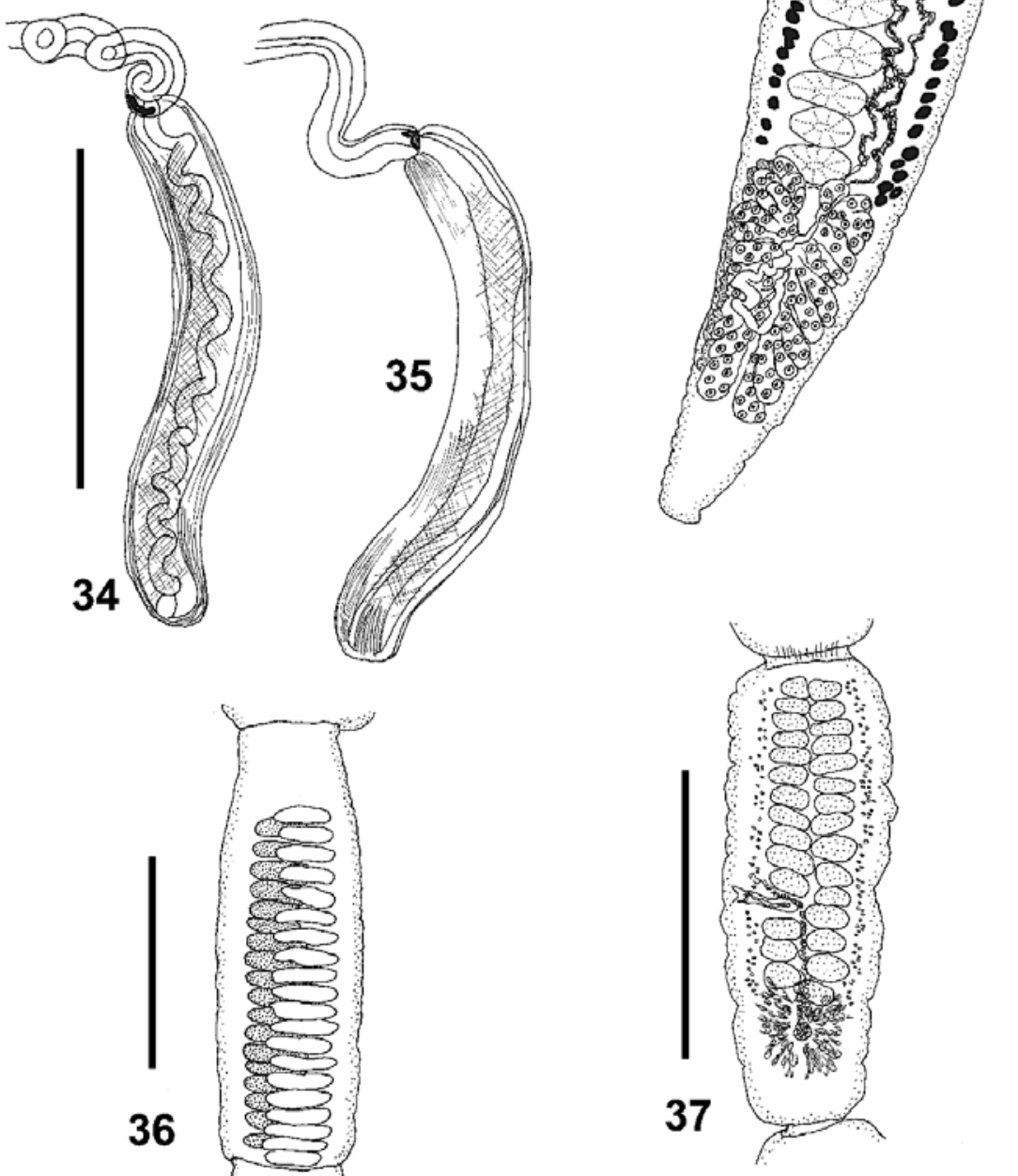

Figs. 32-38. Hemionchos striatus sp. n. from the spiral valve of Mobula thurstoni. Fig. 32. Entire cestode. Fig. 33. Scolex, showing annulation of tegument. Figs. 34, 35. Tentacular bulbs with retractor contracted (Fig. 34) or extended (Fig. 35). Fig. 36. Premature segment, oblique view showing arrangement of testes. Fig. 37. Premature segment. Fig. 38. Mature segment. Scale bars $=$ $0.1 \mathrm{~mm}$. 

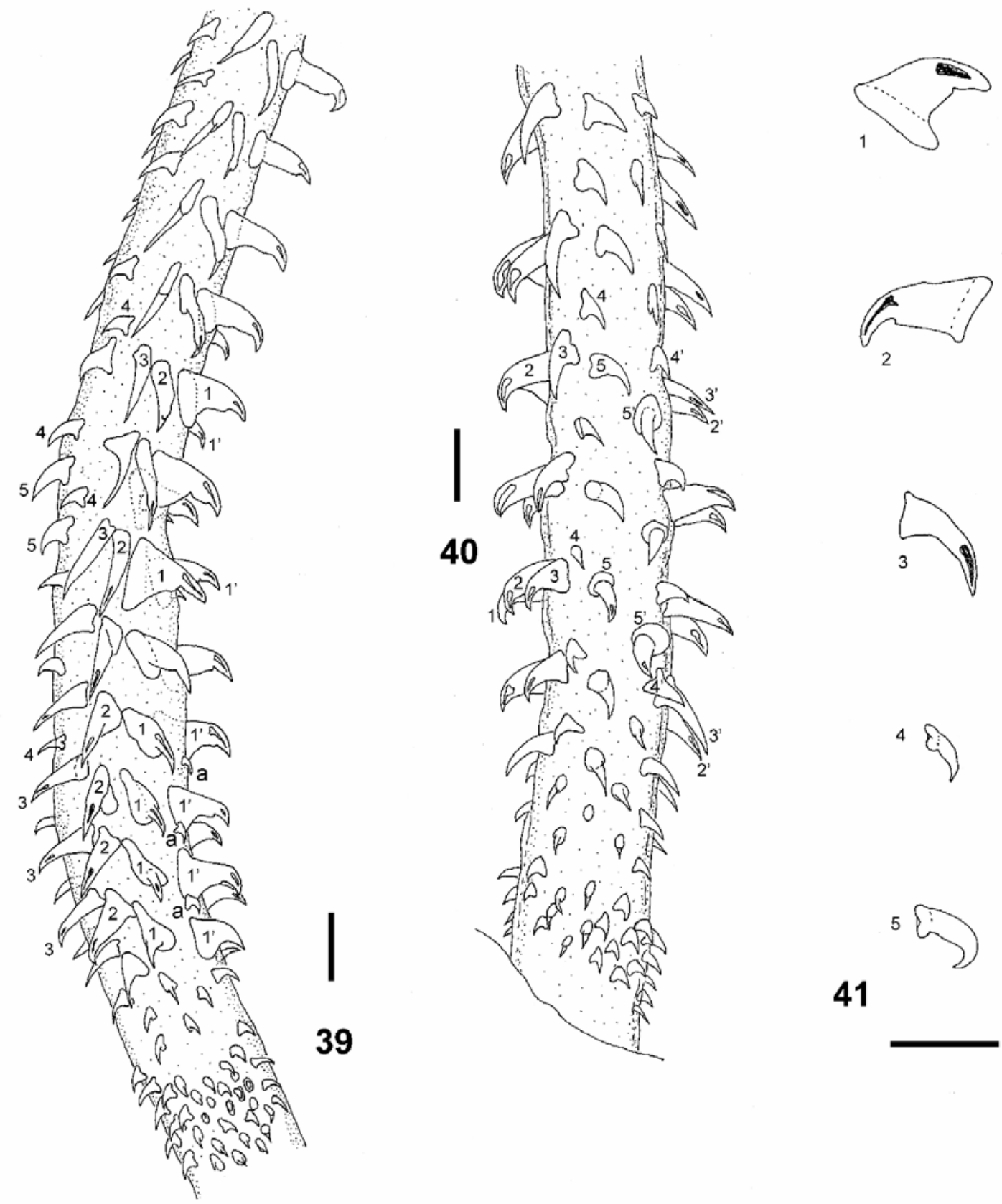

2

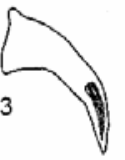

4
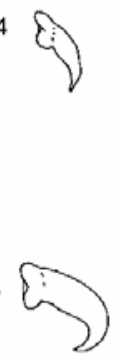

41

Figs. 39-41. Hemionchos striatus sp. n. from the spiral valve of Mobula thurstoni. Tentacular armature. Fig. 39. Internal surface, basal and metabasal regions, bothrial surface on right-hand side. Fig. 40. External surface, basal and metabasal regions, bothrial surface on left-hand side. Fig. 41. Profiles of hooks of principal rows. Scale bars $=0.01 \mathrm{~mm}$.

$(8, \mathrm{n}=5)$; lower aspect of recurved part of hook with distinct, abrupt kink; upper margin of recurved part of hook lacunate, giving hook a semi-rostrate appearance. Hooks 2(2') similar in shape to hooks $1\left(1^{\prime}\right)$, with cavity in hook near tip, length $12-14(13, \mathrm{n}=5)$, base $7-8(8, \mathrm{n}$ $=5)$; hooks 3(3') elongate, uncinate with shorter base, lacunate tip only clearly visible in hooks of lower metabasal region; hooks 3(3') 12-14 (13, n = 5) long, base 5-7 $(6, \mathrm{n}=5)$; hooks $4\left(4^{\prime}\right)$ distinctly separated from hooks 3(3'), displaced anteriorly, much smaller, without lacuna near tip, uncinate, $5-8(7, \mathrm{n}=5)$ long, base 3-4 $(5, \mathrm{n}=5)$; hooks $5\left(5^{\prime}\right) 7-8(7, \mathrm{n}=5)$ long, base 3-5 (4, $\mathrm{n}=5)$; with lacuna at tip in metabasal but not distal region of tentacle; hooks 5(5') larger than hooks 4(4') in metabasal region, of similar size in distal region.

Mature segments acraspedote, 580-930 $(690, \mathrm{n}=10)$ long, 90-160 (120, $\mathrm{n}=10)$ wide; genital pore, in middle of segment margin, $250-630(410, \mathrm{n}=5)$ or $42-68(56$, 
$\mathrm{n}=5) \%$ from posterior end. Testes distributed in two columns; testes $40-93(75, \mathrm{n}=10)$ long by $15-33(25, \mathrm{n}$ $=10)$ wide; total number of testes $22-38(32, \mathrm{n}=10)$ distributed as $2-4(3, \mathrm{n}=5)$ post-vaginal, $8-14(10, \mathrm{n}=$ 5) pre-vaginal and 11-20 $(14, n=5)$ anti-poral. Ovary four-lobed, lobes $110-200(153, \mathrm{n}=10)$ by $30-60(38, \mathrm{n}$ $=10$ ); Mehlis' gland posterior to ovarian isthmus, 33$185(90, \mathrm{n}=5)$ by $25-38(30, \mathrm{n}=5)$. Uterus tubiform, extends from Mehlis' gland almost to anterior extremity of segment. Osmoregulatory canals: ventral canal sinuous, 5-10 $(8, \mathrm{n}=5)$ in diameter. Gravid segments absent.

M a t e r i a 1 e x a m i n e d: Holotype from spiral valve of Mobula thurstoni (Lloyd, 1908), La Paz, Gulf of California, Mexico $\left(24^{\circ} 10^{\prime} \mathrm{N}, 110^{\circ} 17^{\prime} \mathrm{W}\right), 26 . i x .1993$ (IBUNAM 5460); 103 paratypes, same data (IBUNAM 5461-2); 31 specimens, same data, 9.ix.1993 (USNPC 97904), 83 specimens, 25.ix.1993 (LRP 3931-47); 46 specimens, Loreto, Gulf of California, Mexico, 1.ix.1993 (LRP 3948-54); from Mobula japonica: 6 specimens, La Paz, Gulf of California, 26.ix.1993 (USNPC 97905); from Myliobatis californicus: 1 specimen, Loreto, Gulf of California, Mexico, 1.ix.1993 (USNPC 97906).

E t y m o log y: The specific name, striatus, is given because of the prominent transverse annulations on the scolex of this species.

\section{Remarks}

This cestode is unusual in that the orientation of the armature changes along the tentacle. In the metabasal region, the hook rows begin on the internal surface but the hook files spiral along the tentacle, the axis of orientation gradually shifting, so that the hook rows begin on the bothrial surface (Fig. 39). Consequently, some difficulty is encountered in annotating the armature. In Figs. 39 and 40, primes are placed on hook numbers which will eventually be on the external surface of the tentacle, irrespective of the orientation at the origin of the rows.

\section{Hemionchos mobulae sp. n.}

Figs. 42-51

Description. Small cestodes, mature and post-mature specimens $1.25-1.97(1.51, \mathrm{n}=10) \mathrm{mm}$ long, maximum width $110-210(150, \mathrm{n}=10)$, with $2-3(2, \mathrm{n}=10)$ segments; pregravid specimen 1.97 long with 3 segments. Scolex acraspedote $600-850(730, \mathrm{n}=10)$ long, maximum width in region of pars bulbosa 90-140 $(110, \mathrm{n}=$ 10). Tegument of scolex with regular, fine, transverse annulations. Two oval bothria; margin of bothrium entire, with 2 prominent internal ridges running from posterior margin near midline to tentacle orifices; pars bothrialis $110-170(140, \mathrm{n}=10)$, width of bothria 100 $170(120, \mathrm{n}=5)$. Pars vaginalis longer than pars bothrialis, 340-570 (460, $\mathrm{n}=10)$ long; sheaths sinuous. Bulbs 190-300 (240, $\mathrm{n}=10)$ long, 30-45 (38, $\mathrm{n}=10)$ wide; retractor originates at base of bulb; gland cells absent within bulb; prebulbar organ present; pars post bulbosa absent.
Everted tentacle up to 420 long, without prominent basal swelling, 15-20 $(18, \mathrm{n}=10)$ in diameter at base, $11-15(13, \mathrm{n}=10)$ in diameter in metabasal region. Armature heteroacanthous typical, heteromorphous; hooks solid. Distinctive basal armature present, composed of c. 3-4 rows of uncinate hooks, 3-7 (5, n = 5) long, base 3$4(3, n=5)$, some hooks with lacunate tip; uncinate hooks followed distally by c. 3 rows of erect, falcate hooks, blades thick and dorso-ventrally flattened, 8-10 $(9, \mathrm{n}=5)$ long, $3-5(4, \mathrm{n}=5)$ in width at base, $2-3(3, \mathrm{n}$ $=5)$ thick in profile, tip with small mucronate extension and lacuna. Principal rows alternate, begin on bothrial surface, terminate on antibothrial surface; 5 hooks per row; space present between hook files 1 and 1 ' on bothrial surface; additional small hook (a) adjacent to hooks 1 on external surface; 4-6 (5, n = 5) long, base 3$4(3, \mathrm{n}=5)$. Hooks $1\left(1^{\prime}\right)$ erect, uncinate, 9-13 $(12, \mathrm{n}=$ 5) long, base 5-8 $(6, n=5)$; lower aspect of recurved part of hook with distinct, abrupt kink; upper margin of recurved part of hook lacunate, giving hook a semirostrate appearance. Hooks 2(2') stout, falciform, more slender than hooks $1\left(1^{\prime}\right)$, tip lacunate, length 12-14 (13, $\mathrm{n}=5)$, base $3-5(4, \mathrm{n}=5)$; hooks $3\left(3^{\prime}\right)$ elongate, falciform, $10-14(12, \mathrm{n}=5)$ long, base $3-4(4, \mathrm{n}=5)$, shorter but with base of similar length, lacuna near tip smaller and only clearly visible in hooks in lower metabasal region; hooks 3(3'); hooks 4(4') slightly smaller, spiniform, non-lacunate at tip, $8-10(9, \mathrm{n}=5)$ long, base 2-3 (3, n = 5); hooks 5(5') smaller, spiniform, 5-7 (6, n 5) long, base 1-2 (2, $\mathrm{n}=5)$.

Mature segments acraspedote, $380-970(630, \mathrm{n}=10)$ long, $130-180(140, \mathrm{n}=10)$ wide; genital pore in middle of segment margin, $220-550(370, \mathrm{n}=10)$ or $45-72$ $(59, \mathrm{n}=10) \%$ of segment length from posterior end. Testes distributed in two columns; testes 50-80 (63, n = $10)$ by $35-60(45, n=10)$; total number of testes $14-23$ $(17, \mathrm{n}=10)$ distributed as $2-5(3, \mathrm{n}=10)$ post-vaginal, $4-7(5, \mathrm{n}=10)$ pre-vaginal and $7-11(9, \mathrm{n}=10)$ antiporal. Cirrus sac elongate, 47 long, 16 wide, extends anteromedially, reaching midline of segment; cirrus unarmed; distal cirrus straight, proximal region coiled, leading to internal seminal vesicle 30 long, 12 wide; vas deferens enters proximal pole of cirrus sac, coils anteriorly then greatly coiled as it descends towards ovary. Distal vagina straight, thick-walled, extends to midline; proximal vagina sinuous, terminating in seminal receptacle 22 by 16 . Ovary four-lobed, lobes 130-200 (150, n $=10)$ long by $30-70(40, \mathrm{n}=10)$ wide; Mehlis' gland posterior to ovarian isthmus, 60 long by 35 wide. Uterus tubiform, extends from Mehlis' gland almost to anterior extremity of segment. Vitelline follicles circummedullary, 20-30 $(25, \mathrm{n}=10)$ in diameter. Osmoregulatory canals: ventral canal sinuous, 13 in diameter; dorsal canal 5 in diameter. Gravid segments absent.

M a t e r i a l e x a m i n e d: Holotype from spiral valve of Mobula japonica (Müller et Henle, 1841), La Paz, Gulf of 

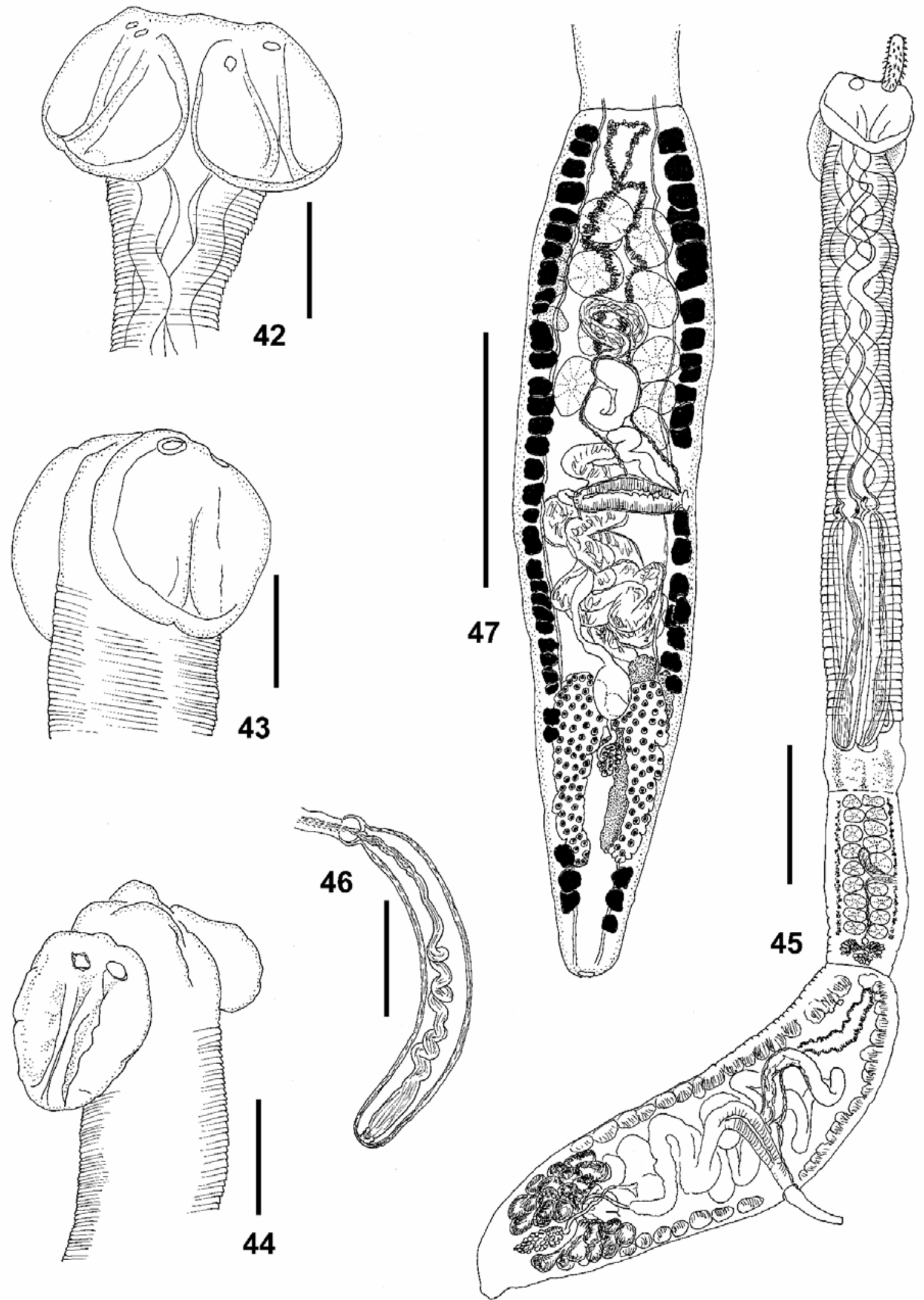

Figs. 42-47. Hemionchos mobulae sp. n. from the spiral valve of Mobula japonica. Figs. 42-44. Views of the bothria. Fig. 45. Entire cestode. Fig. 46. Tentacular bulb. Fig. 47. Mature segment. Scale bars: Figs. 42-44, $46=0.05 \mathrm{~mm}$; Figs. 45 , $47=0.1 \mathrm{~mm}$. 


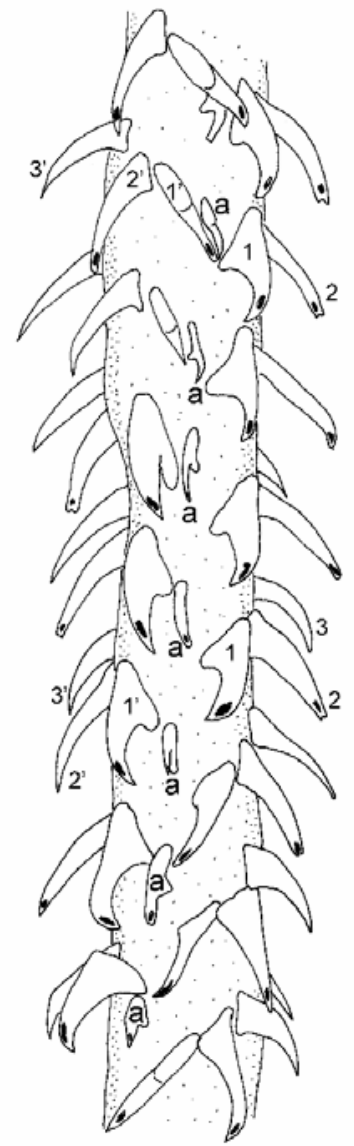

48

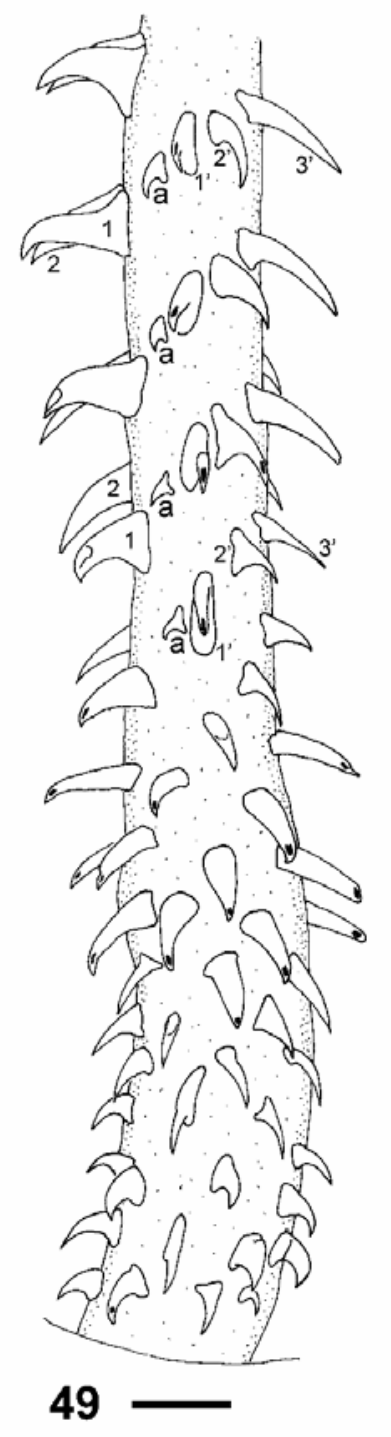

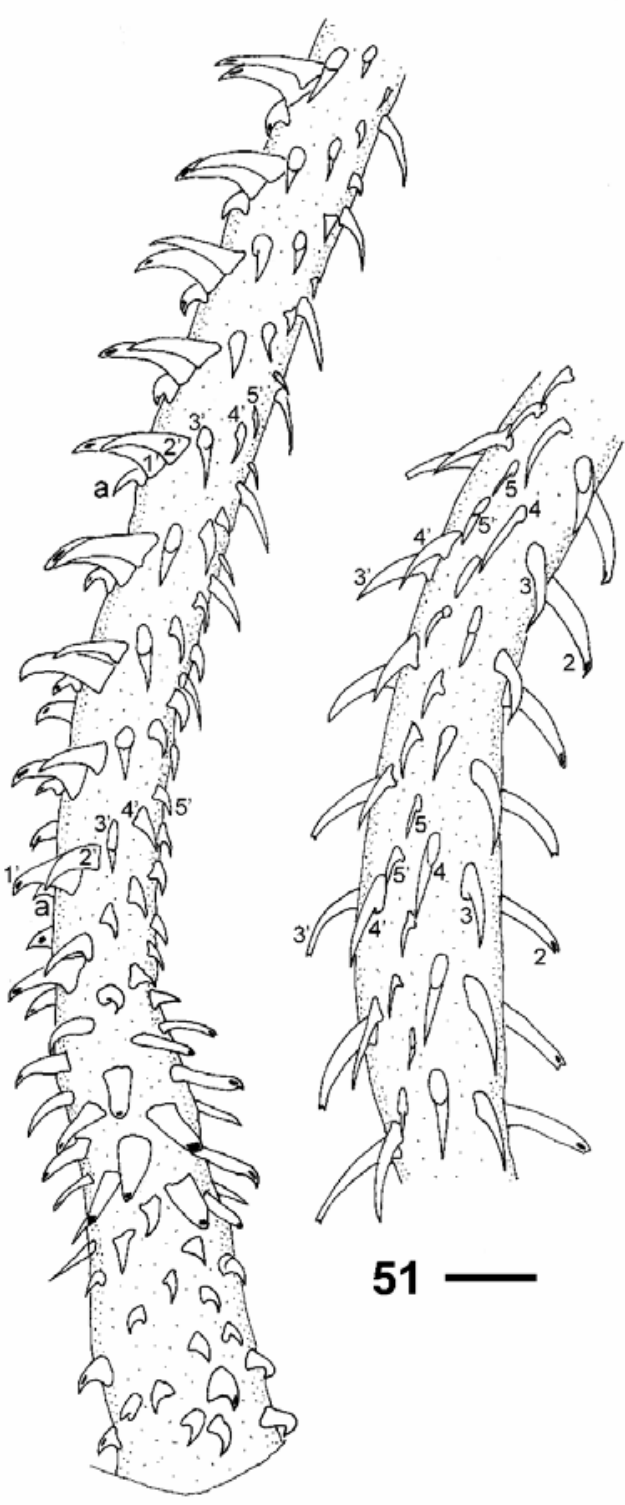

50

Figs. 48-51. Hemionchos mobulae sp. n. from the spiral valve of Mobula japonica. Tentacular armature. Fig. 48. Bothrial surface, metabasal region, beginning six rows anterior to base, external surface on left-hand side. Fig. 49. Bothrial surface, basal and metabasal region, external surface on right-hand side. Fig. 50. External surface, basal and metabasal regions, bothrial surface on left-hand side. Fig. 51. Antibothrial surface, metabasal region, external surface on left-hand side. Scale bars $=0.01 \mathrm{~mm}$.

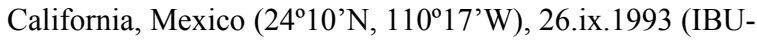
NAM 5463); 101 paratypes, same data, (IBUNAM 5464, USNPC 97907); 49 specimens, Punta Arena, Gulf of California, 22.vi.1996, 24.vi.1996, 27.vi.1996 (LRP 3961-83); from Mobula munkiana Notarbartolo di Sciari, 1987: 5 specimens, Santa Rosalia, Gulf of California, 20.viii.1993 (LRP 3955-56), 7 specimens, Santa Rosalia, Gulf of California, 21.viii.1993 (USNPC 97908), 31 specimens, Loreto, Gulf of California, 31.viii.1993, 1.ix.1993, 2.ix.1993 (IBUNAM 5465, USNPC 97909-11, LRP 3957-60).

$\mathrm{E} \mathrm{t} \mathrm{y} \mathrm{mol}$ o g y : This species is named after the host genus, Mobula.

\section{Remarks}

This species is readily distinguishable from $H$. striatus on the basis of the basal armature, which in $H$. striatus consists of a short band of ascending rows of small, uncinate hooks (Fig. 39). In H. mobulae, by contrast, the external surface of the base bears a number of flattened hooks with a small mucronate tip (Fig. 50). Testis number also distinguishes the species, with 14-23 testes per segment in H. mobulae and 40-93 in H. striatus. As with $H$. striatus, there is a change in the orientation of the armature along the tentacle from internalexternal to bothrial-antibothrial. 


\section{Hemionchos maior sp. n.}

Figs. 52-61

Description. Small cestodes, mature specimens 2.90-3.28 (3.08, $\mathrm{n}=5) \mathrm{mm}$ long, maximum width 150 $480(240, \mathrm{n}=5)$, with $8-9(9, \mathrm{n}=5)$ segments; gravid specimen $5.1 \mathrm{~mm}$ long with 10 segments. Scolex acraspedote $1,090-1,450(1,330, \mathrm{n}=5)$ long, maximum width in region of pars bulbosa 160-200 $(180, n=5)$. Tegument of scolex with regular, fine, transverse annulations. Two oval to sub-quadrate bothria; margin of bothrium entire, with slight posterior indentation; 2 prominent internal ridges diverging from posterior margin near midline to tentacle orifices; pars bothrialis 150 $210(180, \mathrm{n}=5)$, width of bothria $180-220(190, \mathrm{n}=3)$. Pars vaginalis longer than pars bothrialis, 760-950 (840, $\mathrm{n}=5)$ long; sheaths sinuous. Bulbs 350-500 (460, $\mathrm{n}=$ 5) long, 60-70 (62, $\mathrm{n}=5)$ wide; retractor originates at base of bulb; gland cells absent within bulb; prebulbar organ present; pars post bulbosa absent.

Tentacles without prominent basal swelling. Armature heteroacanthous, heteromorphous; hooks solid. Distinctive basal armature present, composed of c. 3 rows of uncinate hooks, without cavity at tip; uncinate hooks followed distally by c. 3 rows of stout, dorsoventrally compressed, uncinate hooks, with lacunate, mucronate tips, 12 long, 8 in width at base, 3 thick in profile. Metabasal armature unknown.

Mature segments acraspedote, 350-860 (550, $\mathrm{n}=5)$ long, 140-240 $(190, \mathrm{n}=5)$ wide; genital pore unilateral, in middle of segment margin, $160-410(280, n=5)$ or $46-55(51, \mathrm{n}=5) \%$ of segment length from posterior end. Testes distributed in two columns; testes $68-105$ $(90, \mathrm{n}=10)$ by $23-58(40, \mathrm{n}=10)$; total number of testes $14-16(15, \mathrm{n}=5)$ with $3(3, \mathrm{n}=5)$ post-vaginal, $4-5$ $(5, \mathrm{n}=5)$ pre-vaginal and $7-8(8, \mathrm{n}=5)$ anti-poral. Cirrus sac elongate, 113-208 (138, $\mathrm{n}=5)$ long, 20-28 (35, $\mathrm{n}=5$ ) wide, extends anteromedially, reaching midline of segment; cirrus unarmed; distal cirrus straight, proximal region coiled, leading to internal seminal vesicle; vas deferens enters proximal pole of cirrus sac, coils anteriorly then greatly coiled as it descends towards ovary. Distal vagina straight, thick-walled, extends to midline; proximal vagina sinuous. Ovary four-lobed, lobes $88-165(118, \mathrm{n}=5)$ by $33-60(48, \mathrm{n}=5)$; Mehlis' gland posterior to ovarian isthmus, 80 in diameter. Uterus tubiform, extends from Mehlis' gland almost to anterior extremity of segment. Vitelline follicles circum-medullary, $25-40(30, \mathrm{n}=10)$ in diameter. Osmoregulatory canals: ventral canal $5-10(8, \mathrm{n}=5)$ in diameter; dorsal canal 3 in diameter; genital ducts pass ventral to osmoregulatory canals. Gravid segment 1,100 by 320 , genital pore $580(53 \%)$ from posterior end; eggs spherical, $23-28(25, \mathrm{n}=10)$ in diameter, with prominent outer membrane.

M a t e r i a 1 e x a m i n e d: Holotype from spiral valve of Mobula japonica (Müller et Henle, 1841), La Paz, Gulf of

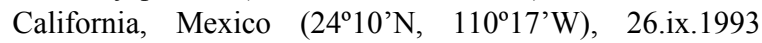

(IBUNAM 5466); 10 paratypes, same data (IBUNAM 5467, USNPC 97912).

E t y $\mathrm{m} \mathrm{o} 1$ o g y: The specific name, maior, meaning larger alludes to the fact that this species is larger than congeners.

\section{Remarks}

This species is clearly distinct from congeners, but is incompletely described as none of the tentacles is fully everted. The basal armature is similar to that of $H$. mobulae, with the characteristic flattened hooks, but the hooks are much larger and more numerous than in $H$. mobulae. The number of testes (14-16) is lower than in congeners, with 14-23 testes per segment in $H$. mobulae and $40-93$ in H. striatus. It is also a significantly larger species, being $2.90-3.28 \mathrm{~mm}$ long compared with $1.25-$ $1.97 \mathrm{~mm}$ in $H$. mobulae and $1.73-2.70 \mathrm{~mm}$ in H. striatus, hence the specific name, maior, meaning larger.

\section{DISCUSSION}

There appear to be no previous records of trypanorhynch cestodes from mobulid rays (Palm 2004), a surprising observation given their prominence, large size and ubiquity in most oceans of the world (Last and Stevens 1994). Most of the cestodes reported here were found in the gall bladder, nephridial system and cloaca and these may be organs in which cestode parasites are not commonly sought. In addition, the cestodes found in the spiral valve are very small and could be easily overlooked. Neither explanation however fully accounts for the fact this array of cestodes has not been described previously.

To date, all adult trypanorhynchs reported have been found in the gastrointestinal tract of their hosts. This is the first report of trypanorhynch cestodes inhabiting the gall bladder or nephridial systems. A number of genera of anoplocephalid cestodes and some hymenolepidid cestodes occur in the biliary system of mammals, but no cestodes have ever been reported from the nephridial/ urinary systems of any vertebrate host.

All three new genera of cestodes described here exhibit novel or unusual morphological characteristics. In most genera of trypanorhynch cestodes, the tentacular armature is oriented with hook rows beginning on the internal surface and terminating on the external surface (Dollfus 1942). In species of the eutetrarhynchid genera Dollfusiella Campbell et Beveridge, 1994 and Prochristianella Dollfus, 1946, hook rows begin on the antibothrial surface and terminate on the bothrial surface (Beveridge et al. 2004). Examination of specimens of Eutetrarhynchus ruficollis (Eysenhardt, 1829), the type species of the genus, in collections of the Naturhistorisches Museum, Vienna (NHMV) (Inv. Nr. 1958) confirmed that in this species also, the hook rows begin on the antibothrial surface. The type and only specimens of Eutetrarhynchus leucomelanus (Shipley et Hornell, 1906) were also examined (NHMV Inv. Nr. 35) but the 

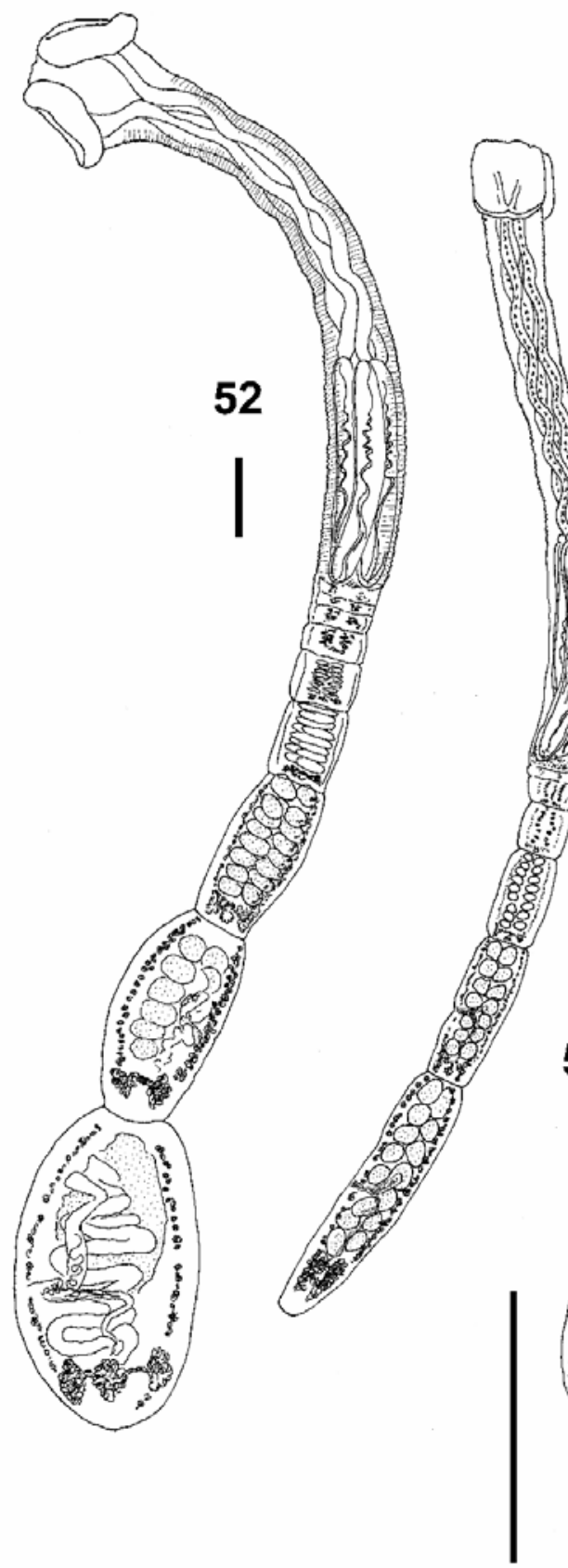

54

53

55
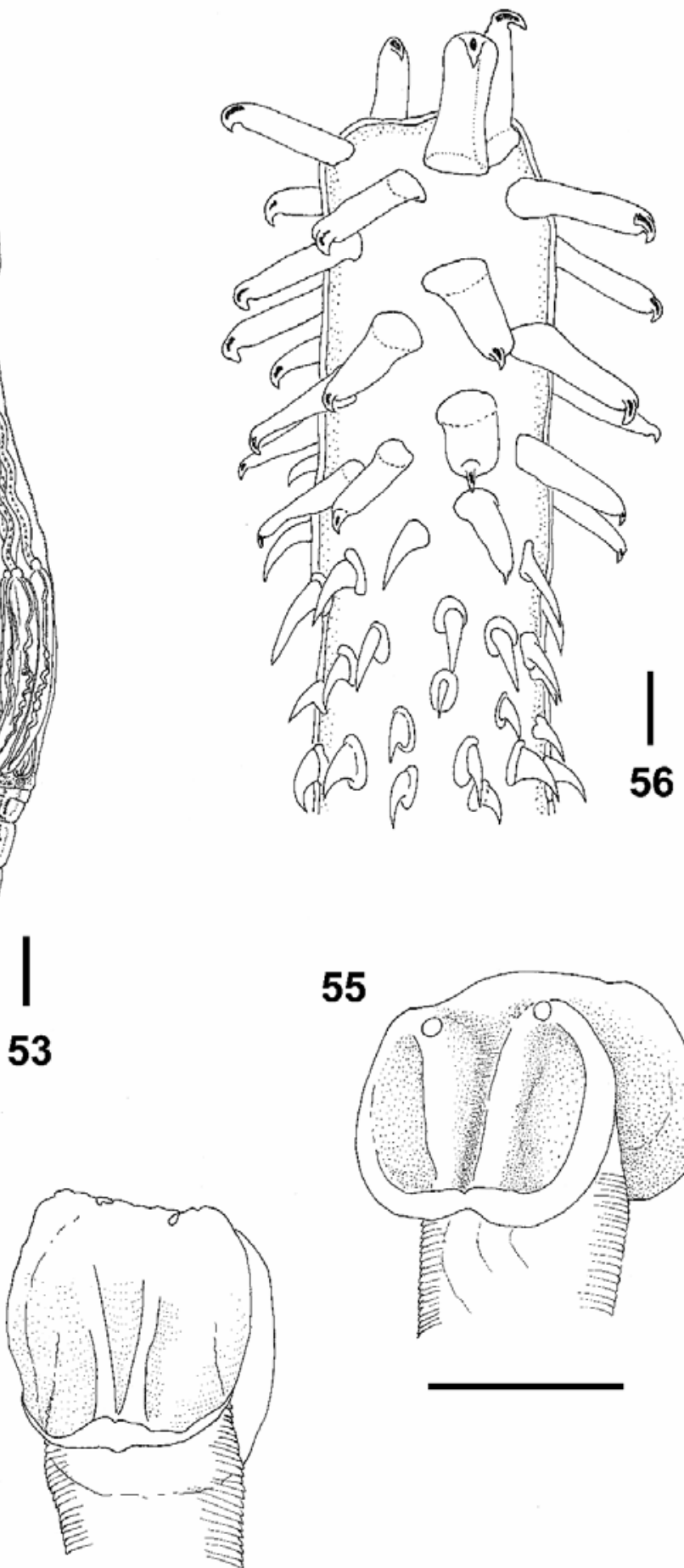

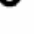

Figs. 52-56. Hemionchos maior sp. n. from the spiral valve of Mobula japonica. Fig. 52. Entire gravid cestode. Fig. 53. Entire mature cestode. Figs. 54, 55. Bothria. Fig. 56. Tentacular armature, external surface, basal region, bothrial surface on left-hand side. Scale bars: Figs. $52-55=1.0 \mathrm{~mm}$; Fig. $56=0.01 \mathrm{~mm}$.

slides were too thick to examine under high magnification. However, it appears that the orientation of the armature in Eutetrarhynchus is similar to Dollfusiella and Prochristianella. In the family Otobothriidae, Pseudotobothrium dipsacum (Linton, 1897) has hook rows originating on the antibothrial surface of the tentacle, while in the congener $P$. arii (Bilqees et Shaukat, 1976), the hook rows begin on the bothrial surface (Beveridge et al. 2000) as they do also in Kotorella pronosoma (Stossich, 1901) (see Campbell and Beveridge 1994). 

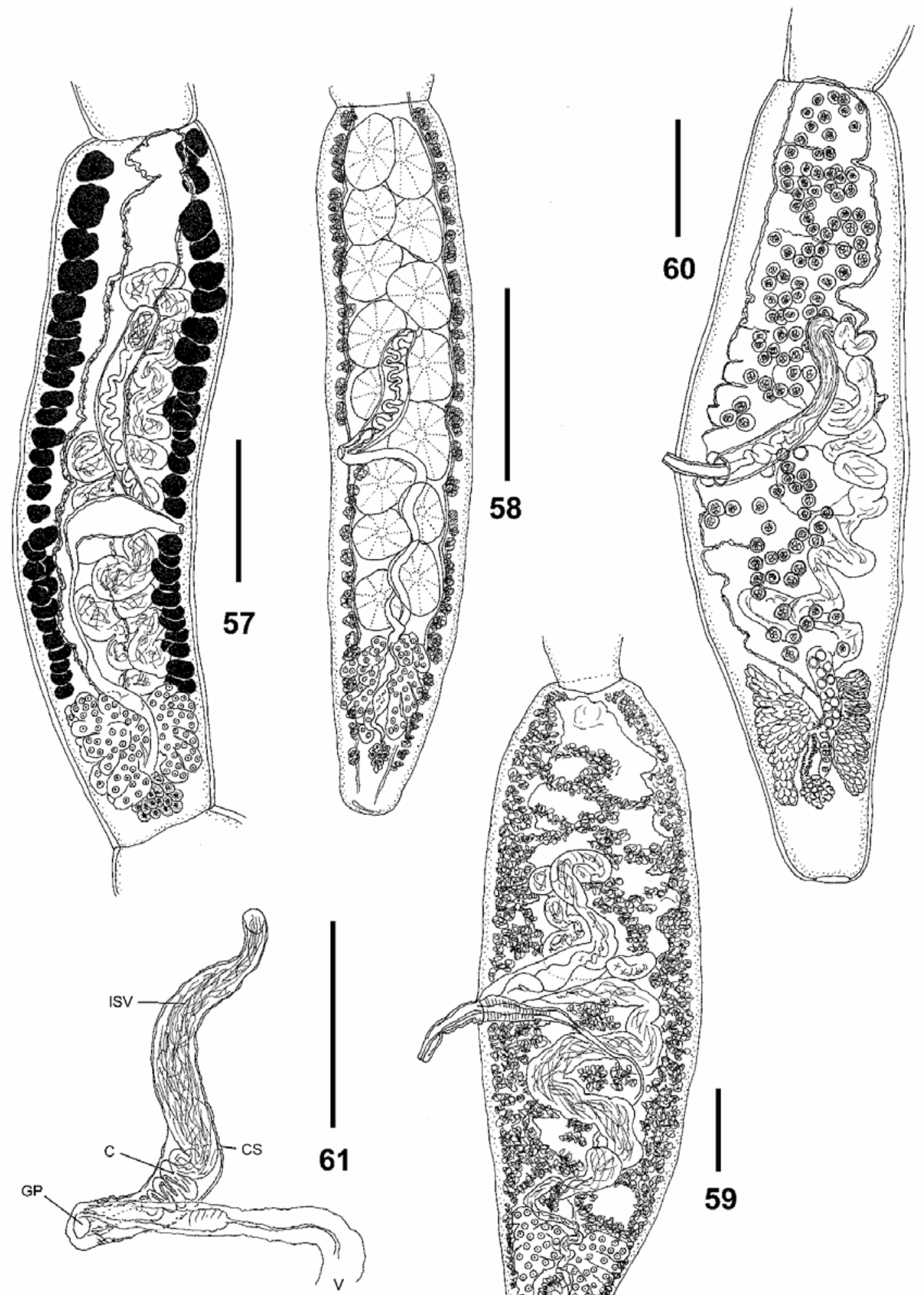

58
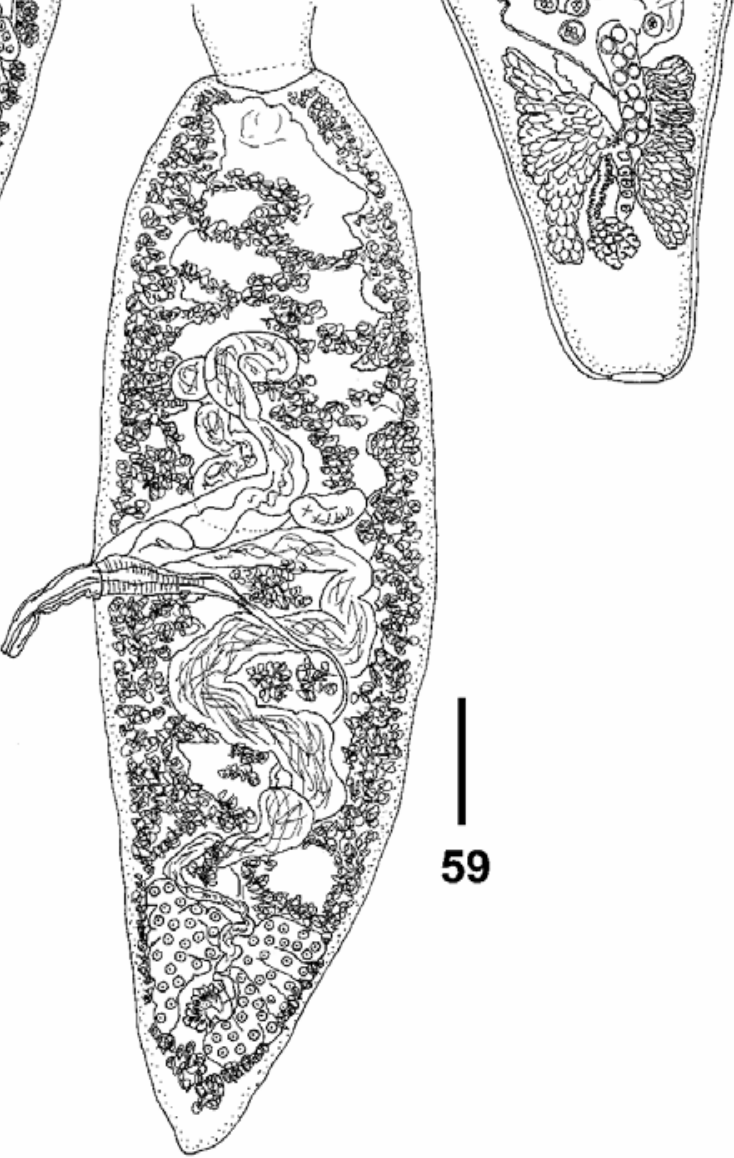

Figs. 57-61. Hemionchos maior from the spiral valve of Mobula japonica. Fig. 57. Post-mature segment with developing uterus. Fig. 58. Mature segment. Fig. 59. Pregravid segment. Fig. 60. Gravid segment. Fig. 61. Cirrus sac. Abbreviations: C - cirrus; CS - cirrus sac; GP - genital pore; ISV - internal seminal vesicle; V - vagina. Scale bars: Figs. 57-60=1.0 mm; Fig. $61=0.1 \mathrm{~mm}$. 
Thus, hook rows originating on the bothrial surface appear to be unusual in trypanorhynch cestodes and the condition has not been reported previously in the family Eutetrarhynchidae. An insight into the possible plasticity of this morphological feature is provided by Hemionchos striatus and $H$. mobulae, in which the orientation of the armature shifts from an internal-external orientation to a bothrial-antibothrial orientation along the metabasal region of the tentacle.

The central file of hooks at the origin of the principal rows on the bothrial surface of the tentacle in Fellicocestus and Mobulocestus appears to be unique within the Trypanorhyncha and could be considered a transitional step between the heteroacanthous and homeoacanthous forms. However, even in homeoacanthous trypanorhynchs such as Heteronybelinia yamagutii (Dollfus, 1960), the large hooks along the midline of the tentacle are paired (Campbell and Beveridge 1994, fig. 7.38) rather than single as in the new genera.

The presence of a small satellite hook adjacent to each hook 1' on the external surface of the tentacle of $H$. striatus and $H$. mobulae is open to a number of interpretations. In the absence of this hook, the origin of the hook rows resembles that found in other eutetrarhynchid genera with divergent armatures such as Prochristianella, Parachristianella Dollfus, 1946, Pseudochristianella Campbell et Beveridge, 1990 and Trimacracanthus Beveridge et Campbell, 1987. In two species of Prochristianella, P. clarkeae Beveridge, 1990, and $P$. hispida (Linton, 1890), hooks 1' are much smaller than hooks 1. However, assigning a number to the initial small hooks (a) in the rows on the tentacles of $H$. striatus and $H$. mobulae would have concealed the symmetry of the remainder of the armature. Whether these additional hooks represent reduced first hooks similar to those seen in some species of Prochristianella or a reduced version of the central file of hooks seen in Fellicocestus and Mobulocestus is not known. Hooks with an apical cavity or lacuna, such as those seen in Mobulocestus and Hemionchos, have not been reported previously in trypanorhynch cestodes.

The three new genera described here belong in the Eutetrarhynchidae Guiart, 1927 as they possess two bothria and a typical, heteroacanthous armature. They are however distinguished from all known eutetrarhynchid genera in the orientation of the tentacular armature, the presence of a central file of hooks (Fellicocestus, Mobulocestus) or of hooks with an apical cavity (Mobulocestus, Hemionchos). The orientation of the armature and the specialised hooks therefore represent two clear synapomorphies for this group of three genera, while the phylogenetic significance of the possession of a central file of hooks is arguable. Nevertheless, the limited data available suggest that these genera possibly represent a separate clade within the Eutetrarhynchidae which has evolved in mobulids. The localisation in the nephridial system and gall bladder could also be viewed as apomorphic characters for two of the genera.

There is an obvious need to examine mobulids from other parts of the world to see if these same genera occur elsewhere and for a formal phylogenetic analysis to investigate the evolutionary implications of these findings.

Acknowledgements. We wish to thank Dr. J.N. Caira of the University of Connecticut, Storrs, Connecticut, USA, for making this material available for study and also to K. Jensen, S. Curran, G. Tyler, P. Cislo, T. Ruhnke, V. McKenzie and P. Olson for assistance with the collection of specimens and reconfirmation of sites of infection. J. McEachran is thanked for host identification. Collecting was funded by National Science Foundation grant DEB 9300796 to J.N. Caira and collections were undertaken under permit number 120496-213-03 issued by the Secretaría de Medio Ambiente Recursos Naturales y Pesca, Mexico.

\section{REFERENCES}

BEVERIDGE I., CAMPBELL R.A., JONES M.K. 2000: New records of the cestode genus Pseudotobothrium (Trypanorhyncha: Otobothriidae) from Australian fishes. Trans. R. Soc. S. Aust. 124: 151-162.

BEVERIDGE I., NEIFAR L., EUZET L. 2004: Eutetrarhynchid cestodes from Atlantic and Mediterranean elasmobranch fishes, with the description of two new species of Dollfusiella Campbell \& Beveridge, 1994 and redescriptions of Prochristianella papillifer (Poyarkoff, 1909) Dollfus, 1957 and Parachristianella trygonis Dollfus, 1946. Syst. Parasitol. 59: 81-102.

CAMPBELL R.A., BEVERIDGE I. 1994: Order Trypanorhyncha Diesing, 1863. In: L.F. Khalil, A. Jones and R.A. Bray (Eds.), Keys to the Cestode Parasites of Vertebrates. CAB International, Wallingford, pp. 51-148.
DOLLFUS R.-P. 1942: Etudes critiques sur les Tétrarhynques du Muséum de Paris. Arch. Mus. Natl. Hist. Nat. 6ème sér. 19: 1-466.

ESCHMEYER W.N. 1998: Catalog of Fishes. California Academy of Sciences, Anaheim, California, 2905 pp.

JONES M.K., BEVERIDGE I., CAMPBELL R.A., PALM H.W. 2004: Terminology of the sucker-like organs of the scolex of trypanorhynch cestodes. Syst. Parasitol. 59: 121126.

LAST P.R., STEVENS J.D. 1994: Sharks and Rays of Australia. CSIRO, Australia, $513 \mathrm{pp}$.

PALM H.W. 2004: The Trypanorhyncha Diesing, 1863. PKSPL-IPB Press, Bogor, 710 pp.

PRITCHARD M.H., KRUSE G.O.W. 1982: The Collection and Preservation of Animal Parasites. University of Nebraska Press, Lincoln, 141 pp. 